\title{
Quantitative Geomorphological and Hydromorphometric Analysis of Drainage Basins of As Sabriyah (Kuwait) Using GIS Techniques
}

\author{
Adeeba Al-Hurban1*, Fawziyah Al-Ruwaih"1, Ahamd Al-Dughairi² \\ ${ }^{1}$ Earth and Environmental Sciences Department, Faculty of Science, Kuwait University, Kuwait City, Kuwait \\ ${ }^{2}$ Department of Geography, Faculty of Arabic Language and Social Studies, Qassim University, Burydah, Kingdom of \\ Saudi Arabia \\ Email: ^q8geo@hotmail.com, *adeeba.alhurban@ku.edu.kw, Farhdana@gmail.com, ahmadam320@gmail.com
}

How to cite this paper: Al-Hurban, A., Al-Ruwaih, F. and Al-Dughairi, A. (2021) Quantitative Geomorphological and Hydromorphometric Analysis of Drainage Basins of As Sabriyah (Kuwait) Using GIS Techniques. Journal of Geographic Information System, 13, 166-193.

https://doi.org/10.4236/jgis.2021.132010

Received: November 30, 2020

Accepted: March 20, 2021

Published: March 23, 2021

Copyright $\odot 2021$ by author(s) and Scientific Research Publishing Inc. This work is licensed under the Creative Commons Attribution International License (CC BY 4.0).

http://creativecommons.org/licenses/by/4.0/

\begin{abstract}
A well-developed drainage network was carved in the study area in a hard calcretized and gypcretized gravelly sand of the Dibdibba Formation (Al-Rukham slope) in pluvial episodes in the post-pleistocene age, and is referred to be paleo-drainage due to the current witnessed aridity. This study aims to investigate the geomorphologic, morphometric, and stratigraphic characteristics of the paleo-drainage system and its role in recharging shallow aquifers. Morphometric analysis was accomplished using GIS and remote sensing techniques. Six vertical pit holes were dug across the area to investigate the stratigraphy and recharging capacity. The drainage system is composed of 10 closely spaced, subparallel, dendritic, elongated, and variant-sloped drainage basins with highest stream order of 5. Water flows NE from Al-Rukham ridge's crest (60 $\mathrm{m}$ a.m.s.l.) downstream in Khor Al-Subiyah coastal flat. The bed rock's hard resistant nature lowered its infiltration and recharging capacity to the shallow aquifer, whereas the coarse-grained wadi fills deposits increased infiltration capacity of the surface sediments, but the water percolation chance is limited as it eventually directed seaward by the same-directed general topography resulting in limiting potential recharge to the shallow aquifers. This is suggested to oppose the salt water intrusion and thus enhance fresh water quality.
\end{abstract}

\section{Keywords}

Drainage System, Morphometric Characteristics, Wadi Fill Deposits, Dendritic Pattern, Calcretic, Gypretic 


\section{Introduction}

The study area (As Sabriyah) is located on the north and the northeastern part of Kuwait adjacent to As Sabbiya area towards the northeast and along the coastal line of Khor As Sabbiya, which separates the area from Bubyan island (Figure 1(a), Figure 1(b)). According to topographic base map of the area (scale 1:250,000, 1995) (Figure 2), the elevation of the study area is ranging from about $2.7 \mathrm{~m}$ at
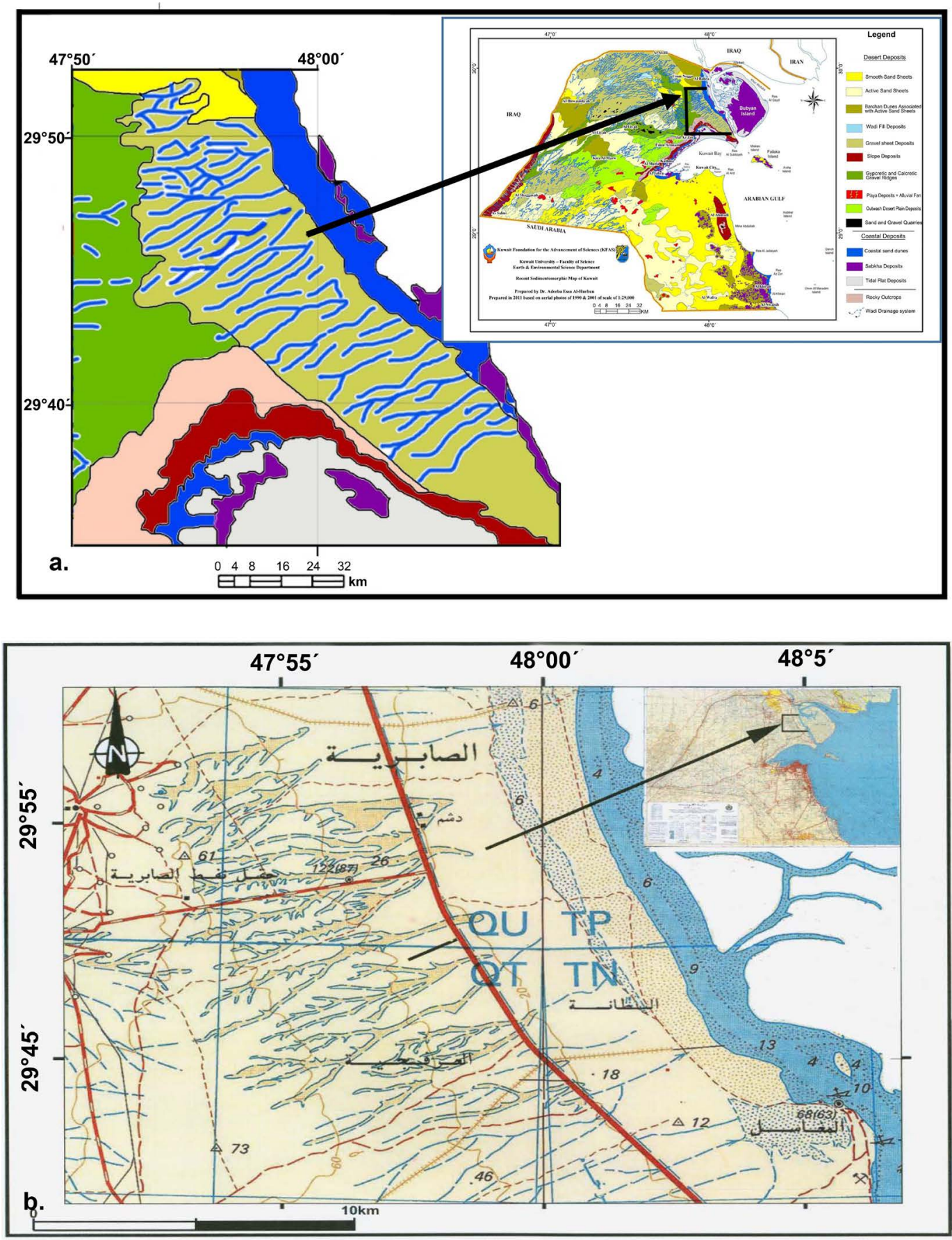

Figure 1. ( $\mathrm{a}, \mathrm{b})$ Maps showing location, topography, sedimentomorphology, and the existing base lines and drainage pattern of the study area (after [1] (a) and [2] (b)). 


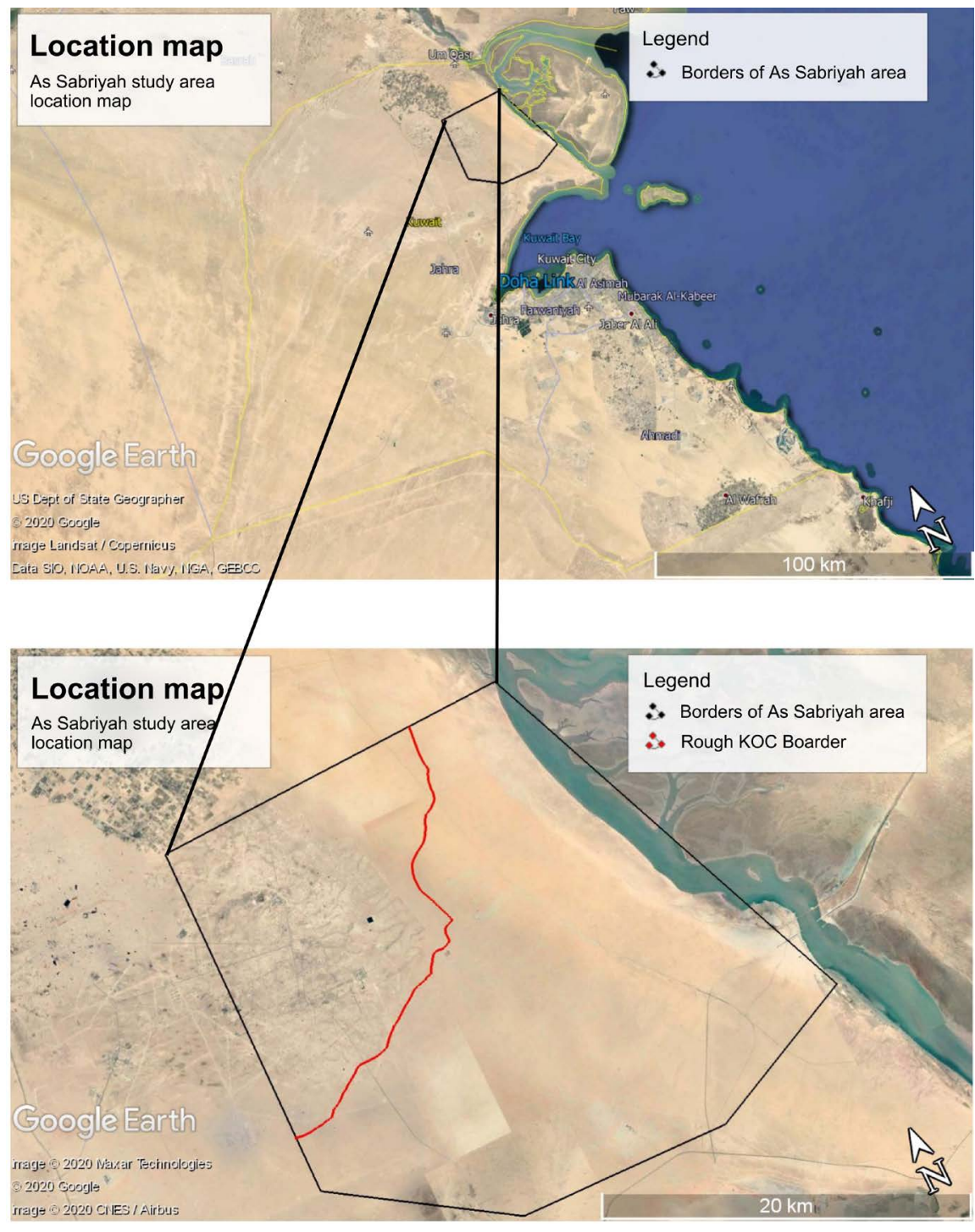

Figure 2. Satellite images showing the location of the study area in the northeastern part of Kuwait. Source: Google Earth (image 2019 CNES/Airbus, 2019 Maxar Technologies).

the coastal parts to about $<60-65 \mathrm{~m}$ heading to the middle inland westward and about $34-36 \mathrm{~m}$ to the west, with geographic coordinates $\left(\mathrm{E} 47^{\circ} 47^{\prime}-48^{\circ} 00^{\prime}\right.$ $48^{\circ} 04^{\prime}, \mathrm{N} 29^{\circ} 42^{\prime}-29^{\circ} 53^{\prime}$ ) and it occupies an area of $\approx 301.056 \mathrm{~km}^{2}$. In As Sabriyah area, a well-developed drainage network was carved in a hard calcretized and gypcretized gravelly sand of the Dibdibba Formation. This drainage network is thought to be developed in pluvial episodes in the post-pleistocene age due to the current aridity that the area witnesses, and therefore they are referred to be paleo-drainage network. This study aims to investigate the geomorphologic, morphometric, and stratigraphic characteristics of the Paleo-drainage system in As Sabriyah area in the north and the northeastern part of Kuwait, in order to assess the role of drainage network in recharging of shallow aquifers. The drainage basins were classified and mapped using GIS and remote sensing applications. The study is also aiming to discuss the environmental implications of the 
studied drainage systems in the study area.

\section{Previous Studies}

The pattern, density and geometry of a drainage system of any geographic area are controlled by several factors. Such factors include the area's morphology, topography, surface geology, and climatic conditions, particularly the rate and frequency of precipitation which plays a significant role in triggering the drainage pattern and retaining it through the action of the surface runoff on the exposed rocks and sediments [3] [4]. The fluctuation in precipitation and the drought periods will directly affect maintaining the drainage system and indirectly the hydrological system and recharge off the shallow aquifers in an area, especially in arid deserts. Therefore, it is essential to study the geomorphological characteristics of the area in order to reveal their influence on the hydrological and environmental conditions of the present-day arid deserts; and in assessing the catchment of the present-day runoff and recharging of shallow aquifers, as well as, the development of soil material.

Though, the literature on drainage morphology in Kuwait is limited, but the drainage system of Jal Az-Zor escarpment was studied [5], as well as its sedimentomorphology [6]. A detailed morphometric analysis of the drainage basins in Kuwait was conducted, in addition to their genesis, their impact on the present-day arid environmental conditions, and the localities of natural recharge and the potential occurrence of limited shallow phreatic aquifers were estimated [3]. Several investigations on the paleodrainge system in Ar-Raudhatain and Umm Alish areas north of Kuwait were conducted [7] [8].

Generally, Kuwait is characterized by a long, dry, hot and windy summer climate that witnesses remarkable diurnal and monthly variations. Annual mean precipitation range is $(23-45 \mathrm{~mm})$. Monthly mean evapotranspiration range is $67 \mathrm{~mm}$ in January to $324 \mathrm{~mm}$ in July. Dust and sandstorms characterize Kuwait's weather, where sandstorms frequently occur in summer, the wind prevailing direction is from northwest and wind speed may exceed $5.5 \mathrm{~m} / \mathrm{s}$.

Kuwait Group is a terrigeneous clastic depositional sequence of Miocene to Pleistocene age, and consists of three formations in the northern part of Kuwait, but barely differentiated in the southern areas (Figure 3(a), Figure 3(b)). These are from bottom to top Ghar, lower Fars and Dibdibba Formations, where Dibdibba is a fluviatile sequence of sands and sandy gravels and covers most of the northern area of Kuwait [1]. This shows that the study area geologically belongs to the upper member of Dibdibba Formations and physiographically, it is located in Al-Dibdibba gravel physiographic province.

\subsection{Geomorphology and Morphostructural Features}

Kuwait is situated on the fringe of two main physiographic regions: the sedimentary sequence of the Arabian monocline to the south and southwest, and the Mesopotamian plain with the Shatt Al-Arab delta to the north and northwest. 


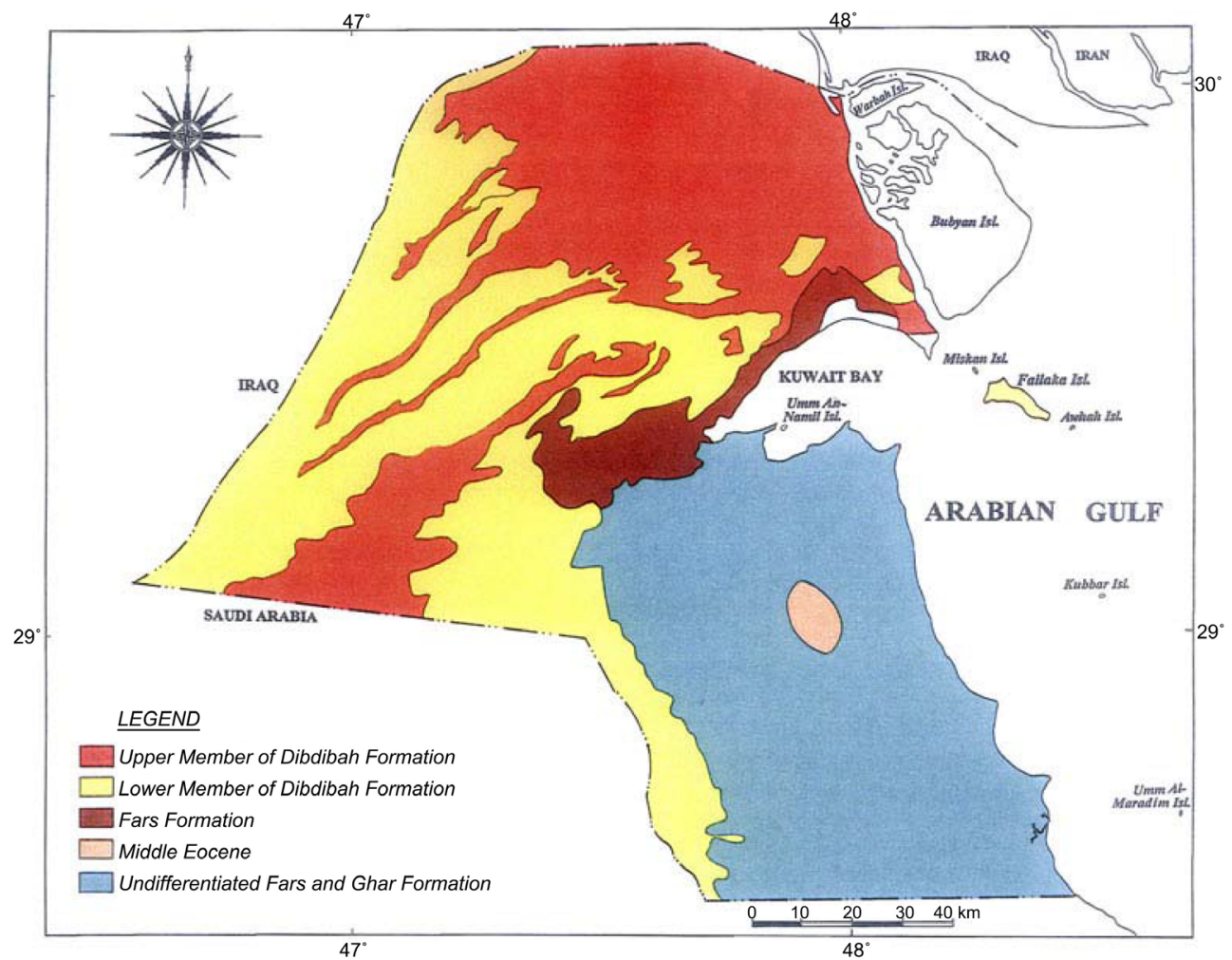

a.

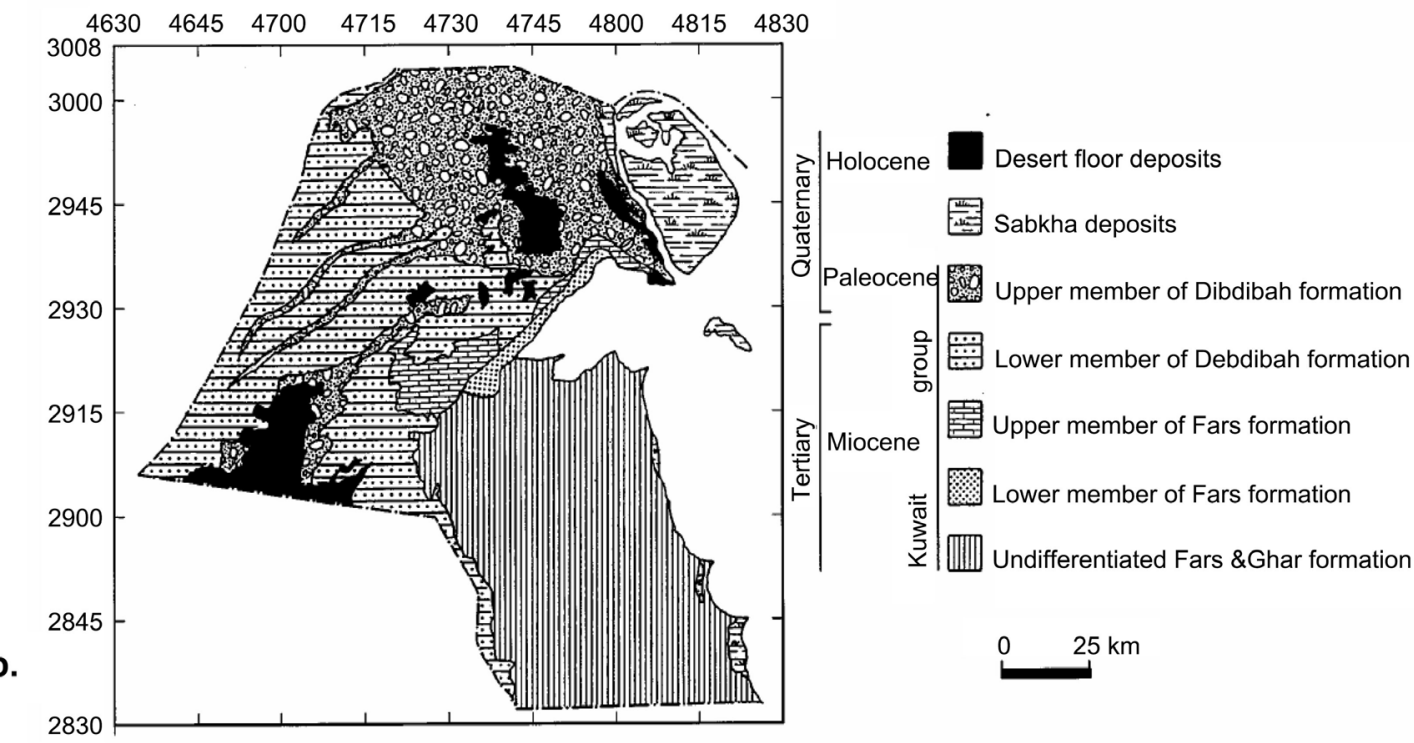

Figure 3. (a, b) Simplified geologic maps of Kuwait: a. geological maps using color (after [9]; and b. a geological map using the distribution of the sediments (after [3]).

Generally, the topographic surface is monotonously flat to gently rolling desert plain broken by occasional low hills, scraps, and shallow inland depressions [3]. The area is gently sloping from about $300 \mathrm{~m}$ a.m.s.l in the extreme southwestern corner towards the Mesopotamian lowland in the northeast. The existing geological structures and lithology of the exposed formations control the morphology of most of the country. Figure 4(a), Figure 4(b)) shows the 15 classified 

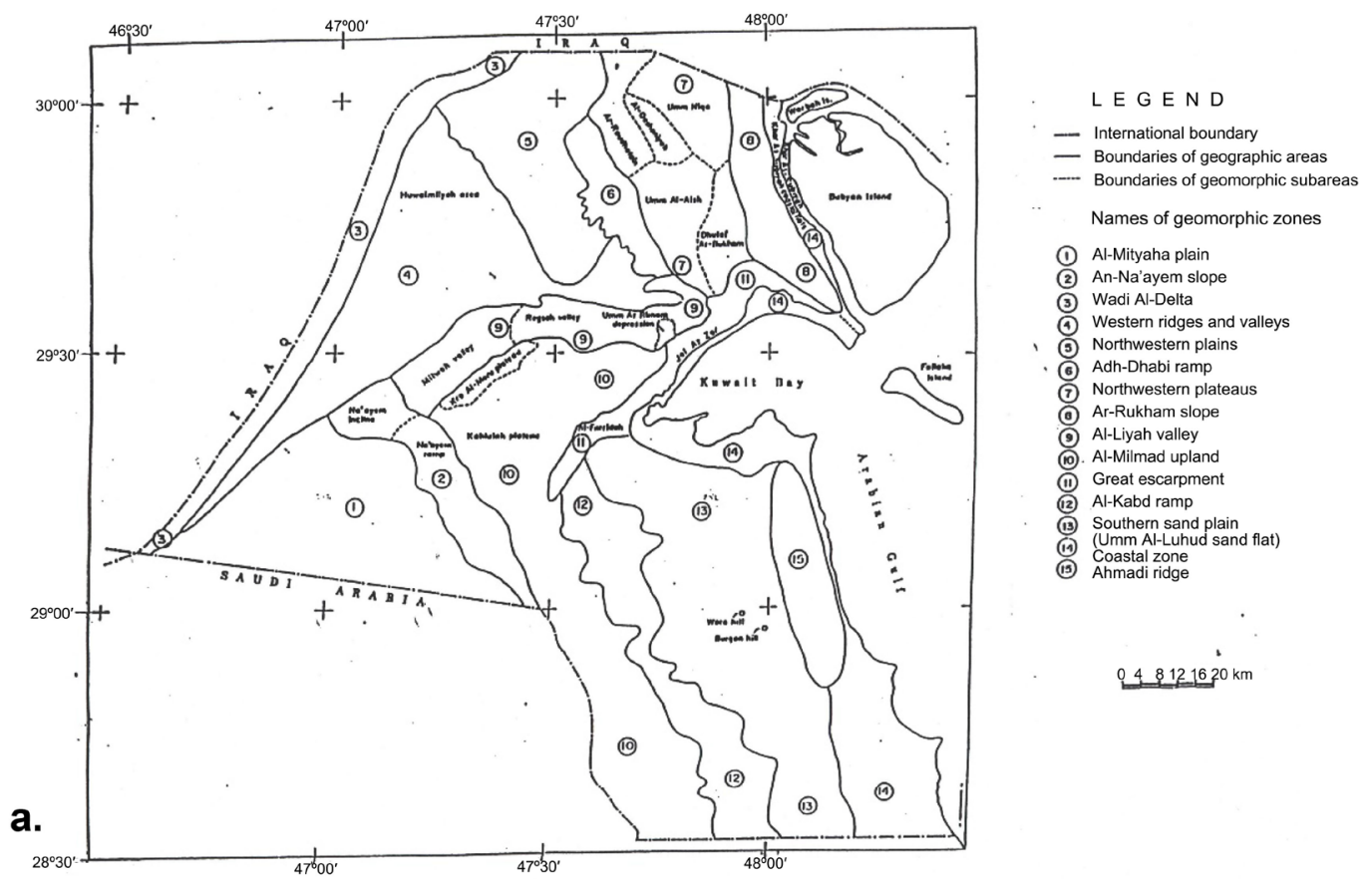

Names of geomorphic zones

(1) Al-Mityaha plain

(2) An-Na'ayem slope

(3) Wadi Al-Delta

(3) Western ridges and valleys

(3) Northwestern plains

(6) Adh-Dhabi ramp

(7) Adh-Dhabi ramp

77) Ar-Rukham slope

(9) Al-Liyah valley

(10. Al-Milmad upland

(iii) Great escarpment

(i1) Al-Kabd ramp

(12) Al-Kabd ramp

(13) Southern sand plain

(ii) Coastal zone

$28^{\circ}$

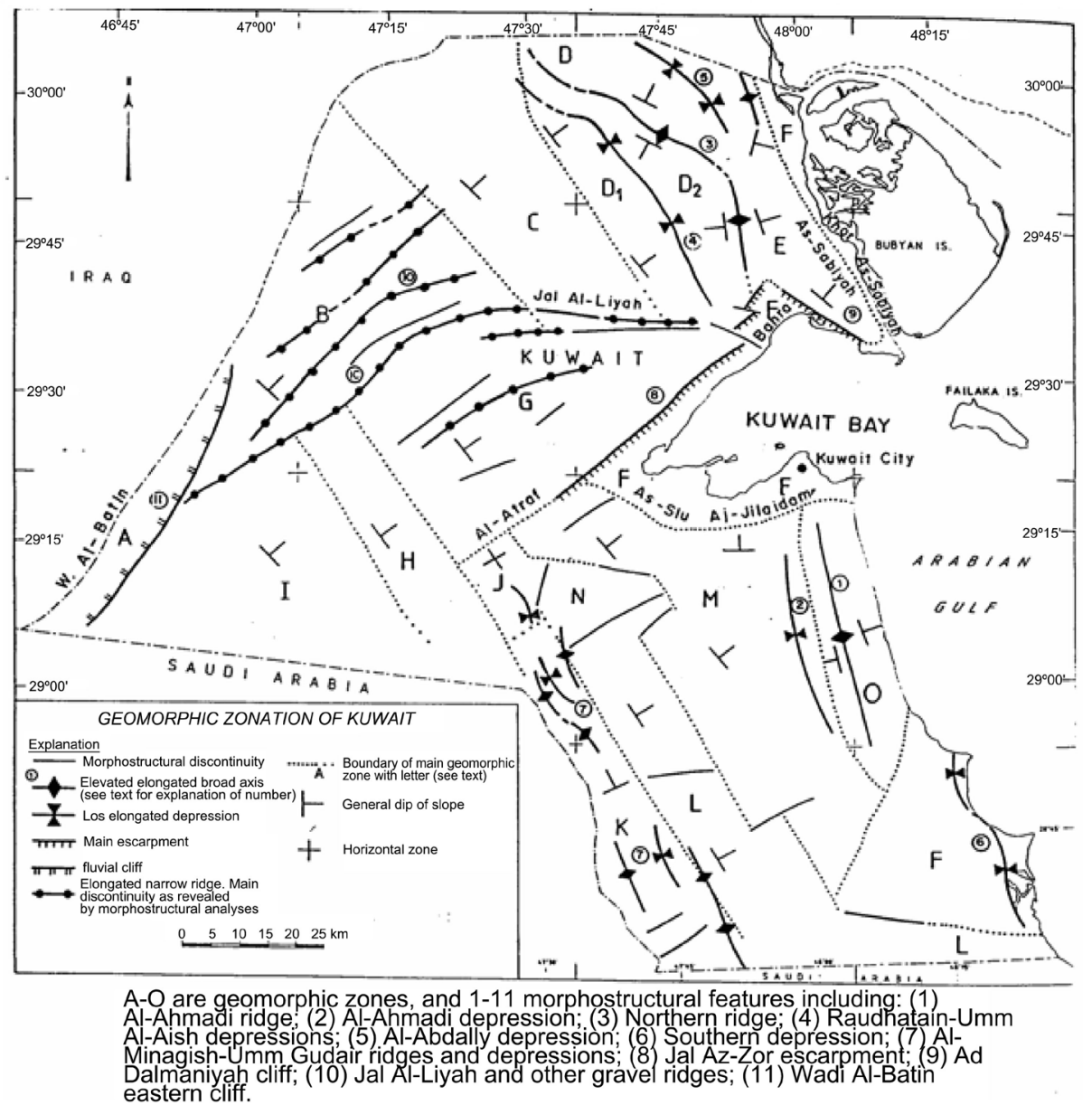

Figure 4. (a, b) Maps showing: (a) the 15 classified geomorphic zones of Kuwait [10] and (b) the classified morphostructural features of Kuwait [4]. 
geomorphic zones of Kuwait [10] showing that the study area is located in morphological zone (8) named Al-Ruham slope. The same figure also shows the classified morphostuctural features of Kuwait surface [4], where the study area is surrounded by morphostructural features (3) the northern ridge, (4) Al-Rawdhatain and Um Al-Aish depression and (5) Al Abdali depression.

\subsection{Hydrogeology}

In general, Kuwait has extremely low surface runoff due to the low precipitation and the dry sandy soils. However, due to severe storms, substantial short duration flows may develop in the areas of integrated surface drainage and accumulated as playa lakes. The accumulated water infiltrates through the Dibdibba Formation to form fresh groundwater lenses in the Kuwait Group in the northern part of the country at Ar-Raudhatain and Umm Al-Aish areas [11]. The lithology of the Kuwait Group controls its content of groundwater, as the existence of local isolated aquicludes (calcrete and/or or mud horizons) divides the Dibdibba Formation into two separate water-bearing horizons (Figure 5(a), Figure 5(b)) (Mukhopadhyay et al., 1996; Al-Sulaimi and Al-Ruwaih, 2004). The water level of the Kuwait Group varies from about 80 - $90 \mathrm{~m}$ above sea level in the southwest to near ground level along the coast [3]. Groundwater generally

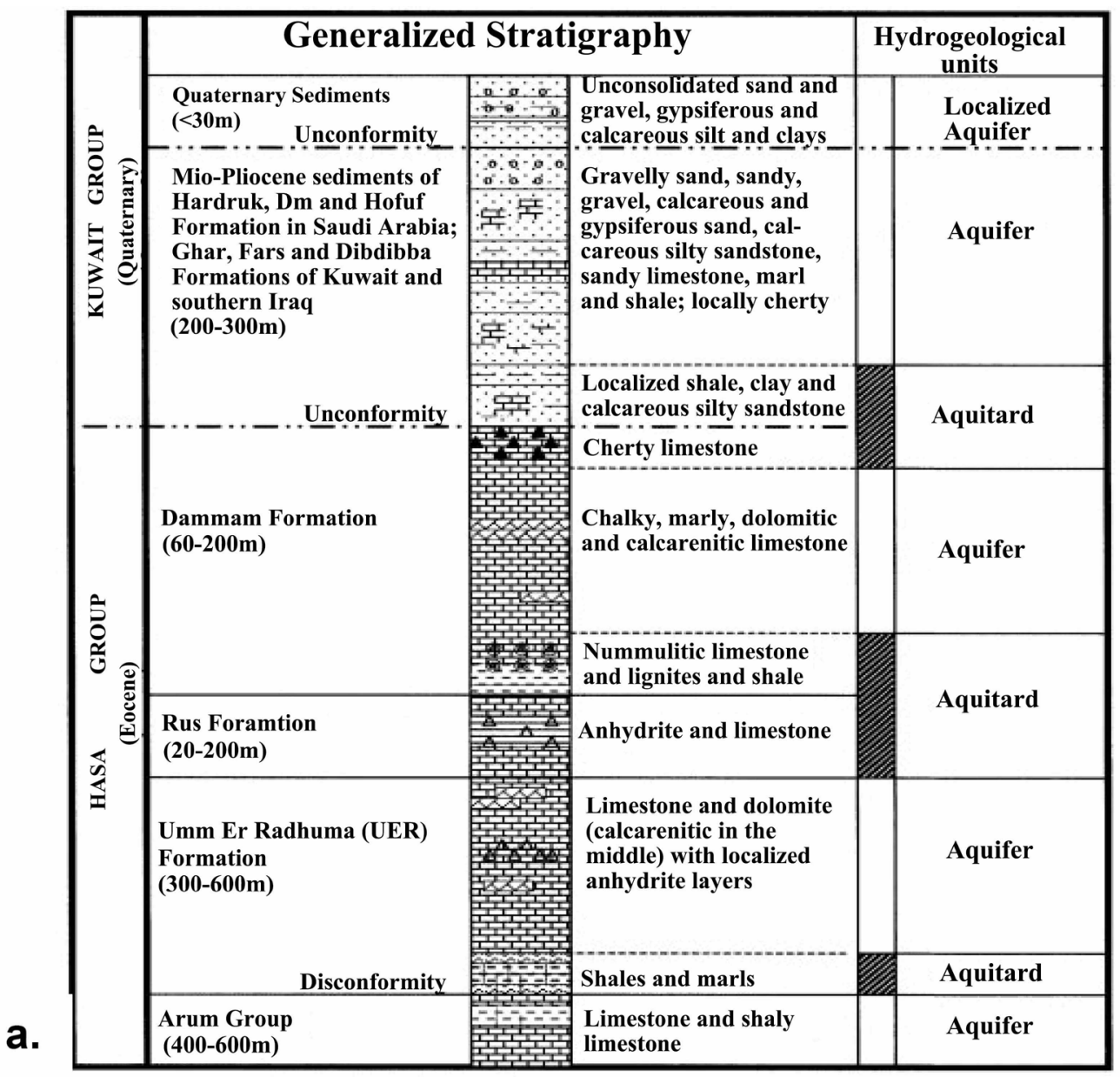




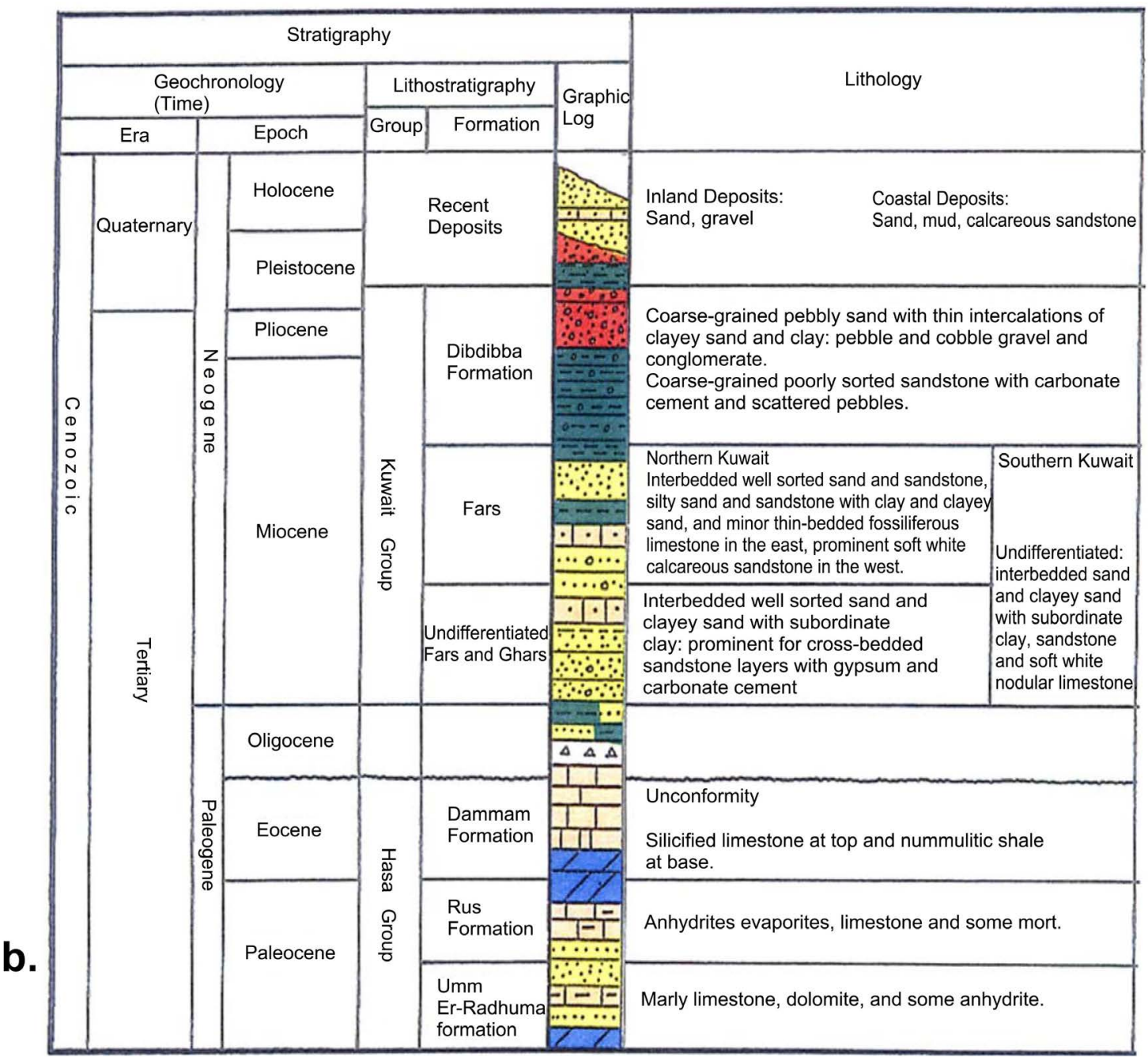

Figure 5. (a) Generalized stratigraphy [15] and hydrogeological units of Kuwait region [16]; and (b) Lithostratigraphic succession for the Kuwait region [17].

flows towards the northeast [12] [13], notifying that upward leakage of groundwater from the Dammam aquifer to the overlying Kuwait Group was confirmed by isotope data [14].

\subsection{Drainage Distribution Pattern}

\subsubsection{The Late Pliocene/Early Pleistocene Phase}

The last intense long humid period took place in late Pliocene/Early Pleistocene between $1.2-3.5$ million years BP. It is characterized by its intense chemical weathering and enormous fluviatile erosion and sedimentation processes from the mainly aeolian processes of the Quaternary. This is evident in the filled-up erosion channels of the ancient drainage system, and directly connected with them are the gravel fans, which declared long ago to the remnants of an intense humid period [18].

Kuwait desert is dissected by drainage systems that vary in patterns and dimensions (Figure 6). Despite the climatic aridity, the drainage patterns show a 


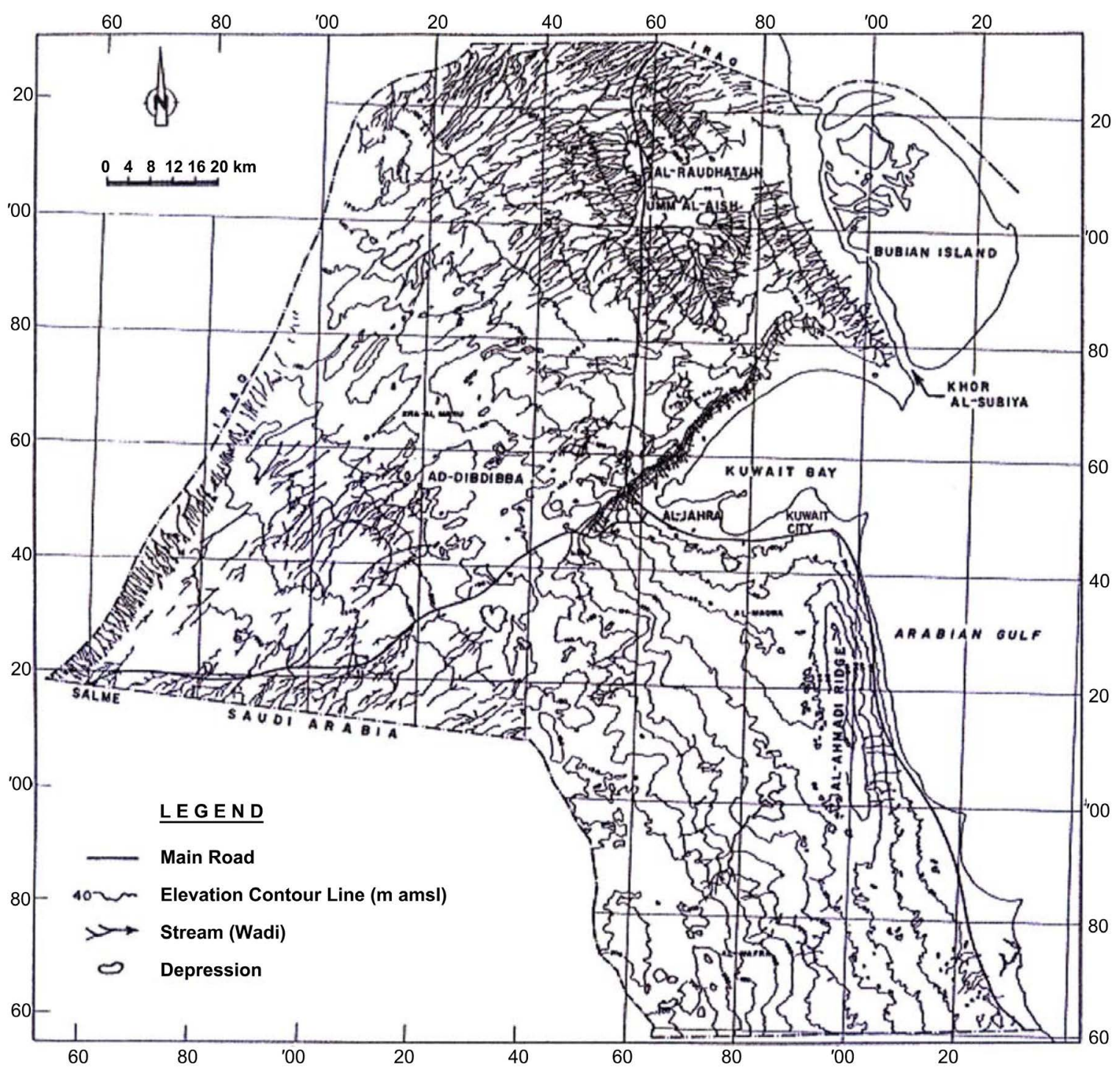

Figure 6. A topographic and drainage systems map of Kuwait (After [20]).

well-developed network in the Dibdibba gravely plain, whereas it is very scarce in the southern sandy flat [3] [19]. Depending on the density and pattern of drainage network, seven drainage zones have been recognized all over Kuwait (Figure 7). Drainage Zone (I) is of prime importance to this research, because the present study area is part of it.

\subsubsection{Zone (I): Al-Rukham Slope Drainage System}

The drainage Zone (I) is developed on Al-Rukham slope (an Arabic term used to describe the debris in their final destiny) covering an area of about $560 \mathrm{~km}^{2}$ and constituted of more than 30 closely spaced sub-parallel to dendritic drainage patterns, grooved into the Upper Member of the gravelly Dibdibba Formation. The drainage channels flow from the water divide along the crest of the Al-Rukham crest (about $60 \mathrm{~m}$ a.m.s.l.) towards northeast ending downstream lies in the Khor Al-Subbiyah coastal flat (Figure 7) (Al-Sulaimi et al., 1997). 


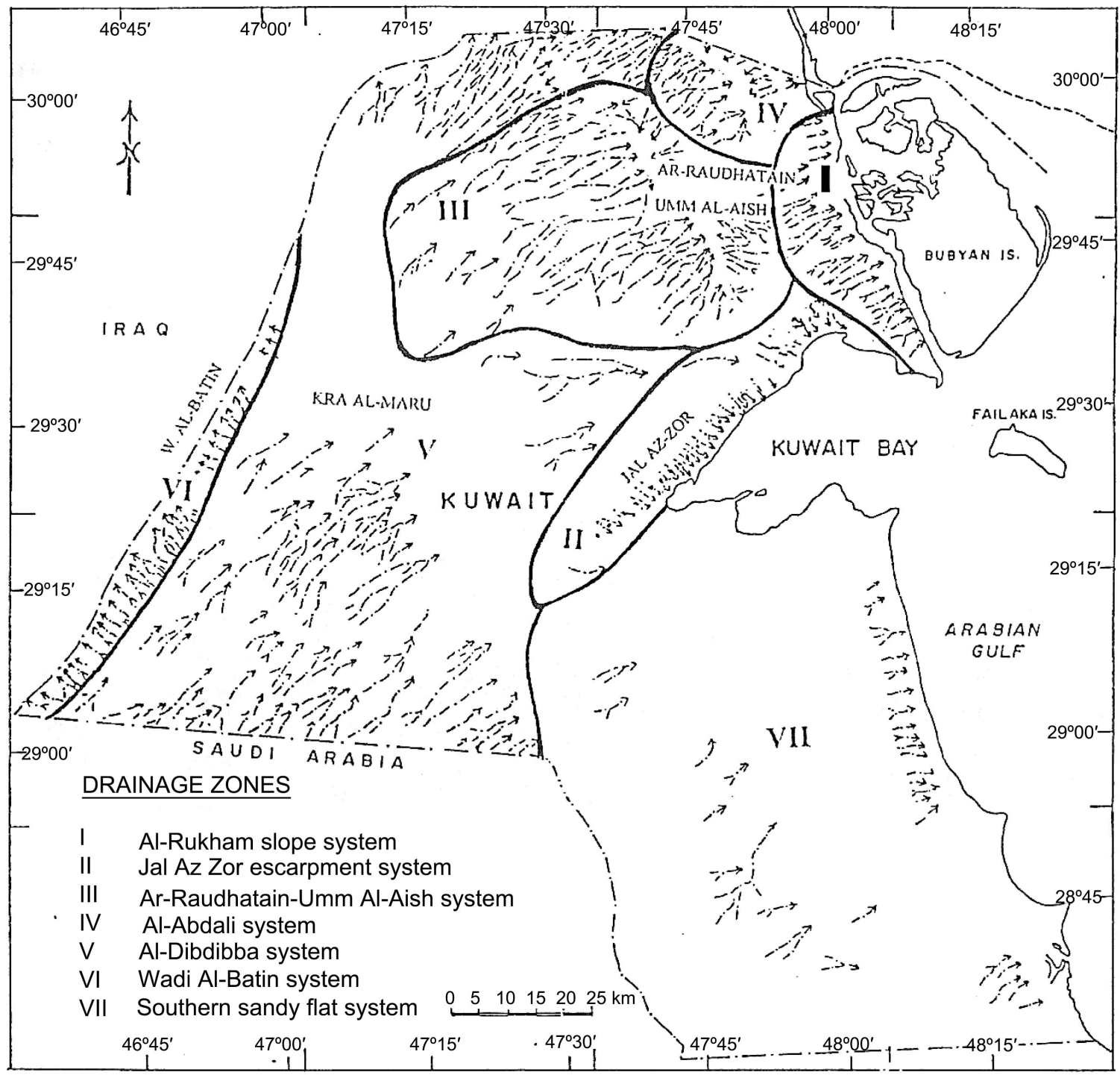

Figure 7. Zonation of drainage systems in Kuwait [3].

\section{Methodology}

\subsection{Field Investigation and Sampling}

Using GIS and remote sensing data, topographic, aspect and slope directions maps were constructed for the drainage network in the study area showing the water divide and the catchment area along with the morphology, pattern, wadis, streams, ephemeral rivers, dry creeks, erosion gullies undulations, tributaries to the main streams, and basins of the well-developed paleo-drainage network carved in the study area.

\subsection{Field Work}

Six sites were located for digging vertical pit holes (Figure 8) encompassing the different identified drainage basins taking into consideration changing between the catchment area and the surrounding arms of the basins, in order to allow 


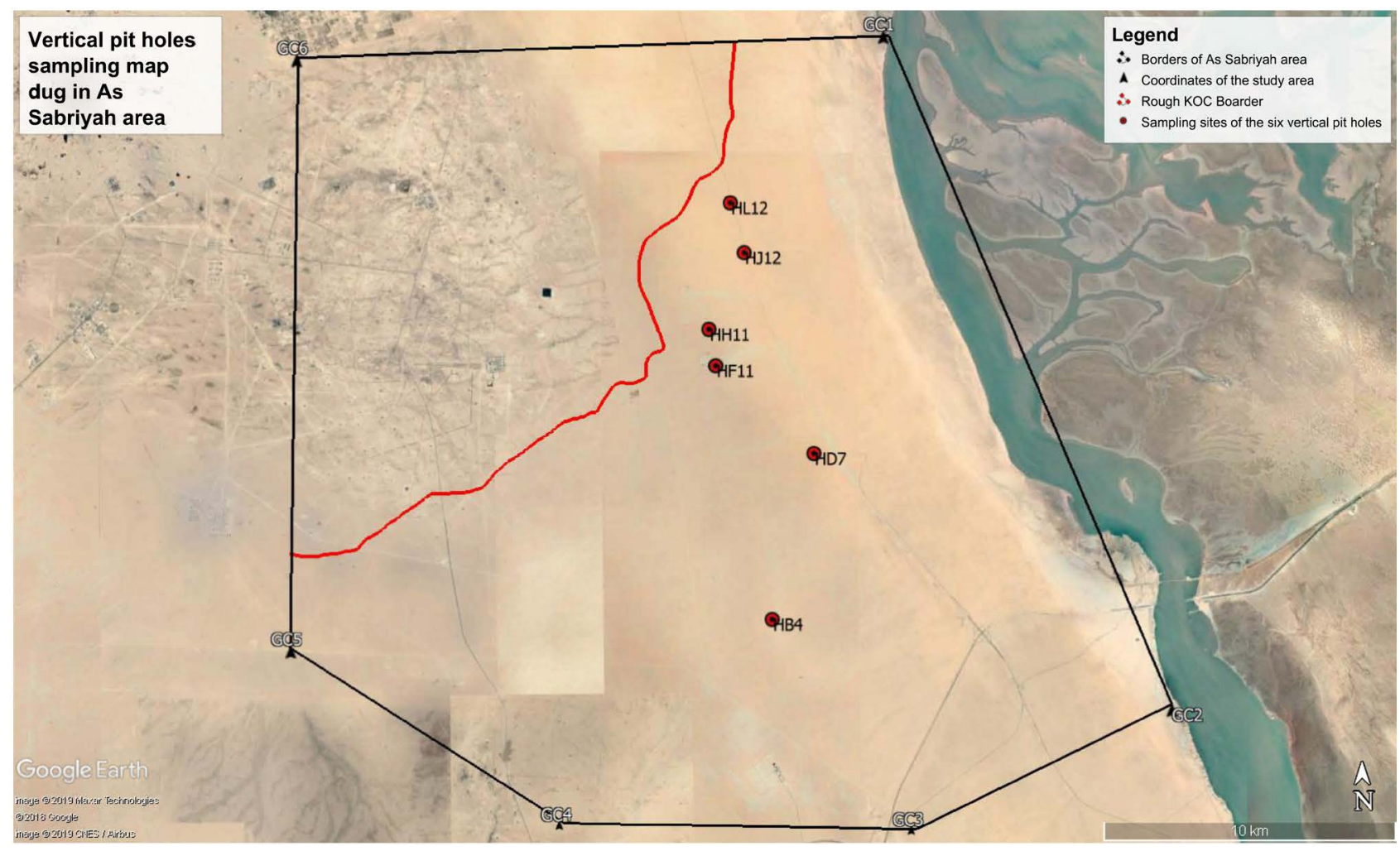

Figure 8. Satellite image showing the sites of the dug vertical pits dug in the study area (As Sabriyah) from which samples were collected at variant depths (source: Google Earth (image 2018 CNES/Airbus, 2018 Digital Globe).

constructing basic stratigraphic information over this large landscape area, due to the absence of previous detailed studies regarding the sedimentary succession and stratigraphy, using an auger sampler. The obtained vertical pit samples were then packed in plastic bags, labeled, described, photographed and transported to labs for sediment and lithological analyses and correlation.

\subsection{Laboratory Investigations}

Different analyses of samples were conducted included: 1) mechanical analysis (grain size analysis); 2) mineralogical analysis ( $\mathrm{x}$-ray diffraction (XRD), $\mathrm{x}$-ray fluorescence (XRF), inductively coupled plasma optical emission spectrometer (ICP-OES) and thin sections).

\subsection{Surface Hydrology (Basin Analysis)}

\subsubsection{Basin Geology and Geomorphology}

The portion of the precipitation which infiltrate may add to the moisture content of the soil or may become groundwater. The most influential factor in determining the steadiness or variability of flow is the source of supply. If the drainage basin in very permeable, as one having coarse sandy soil, there may be almost no surface runoff. The ability of a drainage basin to absorb and detain the water provides a key to the character of the resulting hydrograph and becomes important to the hydrologist. The main geologic factors affecting surface runoff 
are lithology and structure. Lithologic effects are due to the composition, texture and sequence of rocks. To study the basin geomorphology, basin is described by introducing the concept of stream orders [21]. The drainage basin features of hydrologic importance are: elevation, stream length, basin perimeter, drainage area.

\subsubsection{Morphometric Analysis Using ArcHydro GIS Technology and STRM Analysis System}

To obtain information on the spatial variability in processes throughout a watershed requires delineation of the drainage system, which includes the stream channel network and smaller catchments within the basin.

In addition, every watershed can be characterized by geometric properties related to its linear, areal and relief properties. These properties are related to the position of a stream within the watershed, and can be used to compare watersheds. The raster GIS procedures were utilized and ArcHydro, state-of-the-art GIS technology for watershed sciences, was used to delineate the drainage basins and drainage network of the study area. In addition, several indices of drainage basin morphometry, including stream order $\left(N_{\mu}\right)$, stream length $\left(L_{\mu}\right)$, water divide length, basin's area $(A)$, basin's perimeter $(P)$, basin's length $\left(L_{b}\right)$, basin's width $\left(W_{b}\right)$, total basin relief $(H)$, relief ratio $\left(R_{h l}\right)$ and relative relief ratio $\left(R_{h p}\right)$ of the drainage basins, elongation ratio $\left(R_{e}\right)$, circularity ratio $\left(R_{c}\right)$, combination coefficient $\left(C_{c}\right)$, form factor ratio $\left(R_{f}\right)$, ruggedness number $\left(R_{n}\right)$, bifurcation ratio $\left(R_{b}\right)$, drainage density $\left(D_{d}\right)$, and drainage frequency $\left(F_{s}\right)$ were calculated to quantify the morphometry of the watersheds in the study area, using the underneath indicated equations:

Total basin relief:

$$
H=Z-z \quad[22]
$$

Relief ratio:

$$
R_{h l}=H / L_{b} \quad[23]
$$

Relative relief ratio:

$R_{h p}=(H \times 100) / P \quad[24]$

Ruggedness number: $R_{n}=\left(D_{d} \times H\right) / P$ [23]

Circularity ratio: $\quad R_{c}=4 \pi A / P^{2} \quad[25]$

Elongation ratio: $\quad R_{e}=\left(\sqrt[2]{\frac{A}{\pi}}\right) / L_{b}$

Form factor ratio:

$$
R_{f}=A / L_{b}^{2} \quad[21]
$$

Bifurcation ratio:

$$
R_{b}=N_{\mu} /\left(N_{\mu}+1\right) \quad \text { [23] }
$$

Drainage density:

$$
D_{d}=L_{\mu} / A \quad[21]
$$

Drainage frequency: $F_{s}=N_{s} / A \quad$ [21]

where:

$Z=$ Highest elevation inside the basin

$Z=$ Lowest elevation inside the basin

$L_{b}=$ Basin's length (maximum parallel to the main stream (m)

$P=$ Basin's perimeter $(\mathrm{m})$

$A=$ Basin's area $\left(\mathrm{km}^{2}\right)$

$D_{d}=$ Drainage density $\left(\mathrm{km} / \mathrm{km}^{2}\right)$

$P=$ Basin's perimeter $(\mathrm{m})$ 


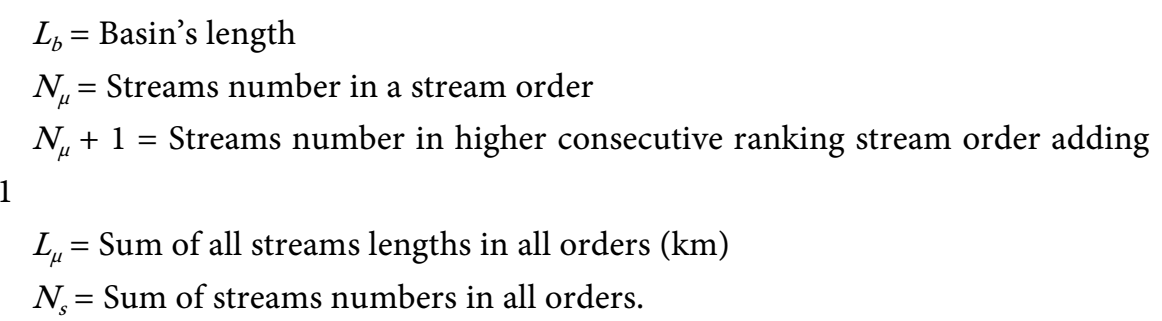

\section{Results \& Discussion}

\subsection{Mechanical Analysis}

Grain Size Analysis

To investigate the grain size distribution of sediments, characterize size parameters, and their possible geological significance the collected sub-lag samples of sand nature were analyzed in the laboratory using standard sieving (The U. S. standard Set of Sieves) and sedimentation techniques [26] [27]. The obtained data were graphically represented by histograms and cumulative frequency curves, which were used in the identification of the various textural parameters for these samples. These parameters are mode, median, mean, sorting, skewness, and kurtosis. Interrelationships of these size parameters were constructed. Table 1 shows the mechanical analysis results along with the statistical textural parameters.

Table 1. The mechanical analysis results along with the statistical textural parameters.

\begin{tabular}{|c|c|c|c|c|c|c|c|c|c|c|c|c|c|c|c|c|c|c|c|c|c|c|}
\hline & \multirow{2}{*}{ Sample } & \multicolumn{7}{|c|}{ Grain Size } & \multicolumn{8}{|c|}{ Cumulative Weight \% } & \multirow{3}{*}{ Mode } & \multirow{3}{*}{ 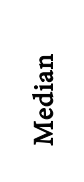 } & \multirow{3}{*}{ 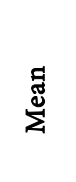 } & \multirow{3}{*}{ 苞 } & \multirow{3}{*}{ 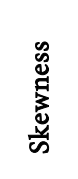 } & \multirow{3}{*}{ 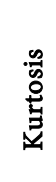 } \\
\hline & & \multirow{2}{*}{ ¿ } & \multirow{2}{*}{$\frac{\text { V.C. }}{\text { Sand }}$} & \multirow{2}{*}{$\begin{array}{c}\text { C. } \\
\text { Sand }\end{array}$} & \multirow{2}{*}{$\begin{array}{c}\text { M. } \\
\text { Sand }\end{array}$} & \multirow{2}{*}{$\begin{array}{c}\text { F. } \\
\text { Sand }\end{array}$} & \multirow{2}{*}{$\frac{\text { V.F. }}{\text { Sand }}$} & \multirow{2}{*}{$\stackrel{0}{\Xi}$} & \multirow{2}{*}{ 实 } & \multirow{2}{*}{ 总 } & \multirow{2}{*}{$\begin{array}{l}\text { V.C. } \\
\text { Sand }\end{array}$} & \multirow{2}{*}{$\begin{array}{c}\text { C. } \\
\text { Sand }\end{array}$} & \multirow{2}{*}{$\begin{array}{c}\text { M. } \\
\text { Sand }\end{array}$} & \multirow{2}{*}{$\begin{array}{c}\text { F. } \\
\text { Sand }\end{array}$} & \multirow{2}{*}{$\frac{\text { V.F. }}{\text { Sand }}$} & \multirow{2}{*}{$\stackrel{0}{\Xi}$} & & & & & & \\
\hline & No. & & & & & & & & & & & & & & & & & & & & & \\
\hline 1 & HB4-1 & 17.43 & 13.36 & 15.13 & 18.98 & 20.41 & 13.09 & 1.6 & 100 & 17.43 & 30.79 & 45.92 & 64.9 & 85.31 & 98.4 & 100 & $\begin{array}{c}-3.0 /-1.25 / \\
1.25 / 1.75\end{array}$ & 0.99 & 0.79 & 1.95 & -0.21 & 0.87 \\
\hline 2 & HB4-2 & 29.79 & 17.01 & 15.91 & 16.9 & 12.77 & 6.34 & 1.28 & 1002 & 29.79 & 46.8 & 62.71 & 79.61 & 92.38 & 98.72 & 100 & $\begin{array}{c}-3.0 /-1.25 / \\
1.25\end{array}$ & -0.01 & -0.02 & 2.17 & -0.08 & 1.01 \\
\hline 3 & HB4-3 & 54.05 & 17.43 & 12.71 & 10.12 & 4.02 & 1.38 & 0.29 & 100 & 54.05 & 71.48 & 84.19 & 94.31 & 98.33 & 99.71 & 100 & -3.0 & -1.42 & -1.74 & 2.66 & -0.21 & 1.04 \\
\hline 4 & HB4-4 & 65.85 & 12.29 & 9.62 & 8.59 & 2.43 & 1 & 0.22 & 100 & 65.85 & 78.14 & 87.76 & 96.35 & 98.78 & 99.78 & 100 & -2.4 & -2.46 & -3.00 & 3.58 & -0.26 & 0.93 \\
\hline & Average & 41.78 & 15.02 & 13.34 & 13.6 & 9.908 & 5.45 & 0.8 & 100 & 41.8 & 56.8 & 70.15 & 83.79 & 93.7 & 99.15 & 100 & & -0.7 & -1 & 2.6 & -0.2 & 0.96 \\
\hline 5 & HD7-1 & 22.68 & 15.55 & 14.6 & 19.31 & 19.1 & 7.9 & 0.86 & 1002 & 22.68 & 38.23 & 52.83 & 72.14 & 91.24 & 99.14 & 100 & $\begin{array}{c}-3.0 /-1.25 / \\
1.25 / 2.75\end{array}$ & 0.60 & 0.50 & 1.98 & -0.16 & 0.91 \\
\hline 6 & HD7-2 & 61.34 & 11.96 & 10 & 8.56 & 5.08 & 2.38 & 0.68 & 100 & 61.34 & 73.3 & 83.3 & 91.86 & 96.94 & 99.32 & 100 & $-3.0 /-1.25$ & -2.45 & -4.09 & 5.68 & -0.45 & 0.94 \\
\hline 7 & HD7-3 & 44.3 & 19.89 & 15.12 & 11.95 & 5.93 & 2.51 & 0.3 & 100 & 44.3 & 64.19 & 79.31 & 91.26 & 97.19 & 99.7 & 100 & $\begin{array}{c}-3.0 /-1.25 / \\
0.75\end{array}$ & -0.99 & -1.03 & 2.25 & -0.08 & 1.15 \\
\hline 8 & HD7-4 & 58.36 & 15.58 & 10.66 & 9.47 & 3.75 & 1.63 & 0.55 & 100 & 58.36 & 73.94 & 84.6 & 94.07 & 97.82 & 99.45 & 100 & $\begin{array}{c}-3.0 /-1.25 / \\
0.75\end{array}$ & -1.67 & -2.44 & 3.51 & -0.35 & 0.99 \\
\hline & Average & 46.67 & 15.75 & 12.60 & 12.32 & 8.47 & 3.61 & 0.60 & 1004 & 46.67 & 62.42 & 75.01 & 87.33 & 95.80 & 99.40 & 100 & & -1.13 & -1.77 & 3.36 & -0.26 & 1.00 \\
\hline 9 & HF11-1 & 47.55 & 20.34 & 13.95 & 8.87 & 5.67 & 3.22 & 0.4 & 100 & 47.55 & 67.89 & 81.84 & 90.71 & 96.38 & 99.6 & 100 & $\begin{array}{c}-3.0 /-1.25 / \\
2.75\end{array}$ & -1.12 & -1.18 & 2.31 & -0.06 & 1.22 \\
\hline
\end{tabular}




\section{Continued}

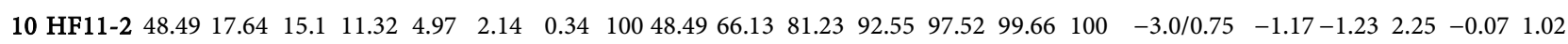

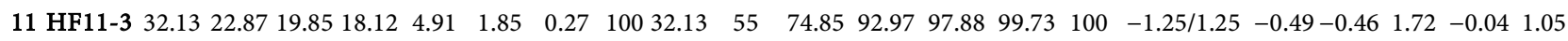

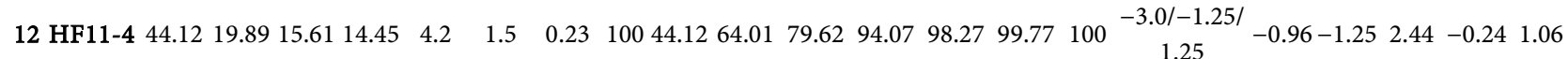

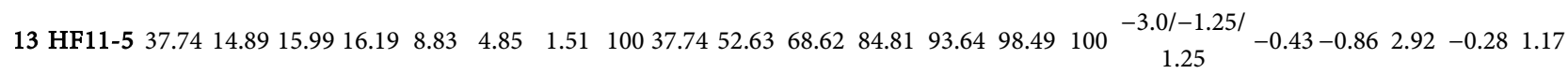

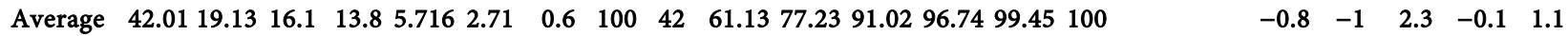

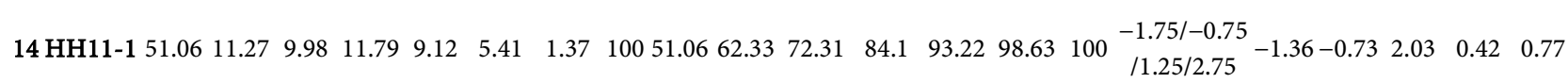

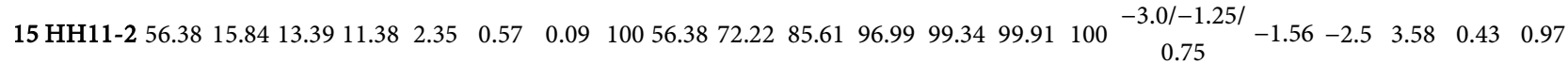

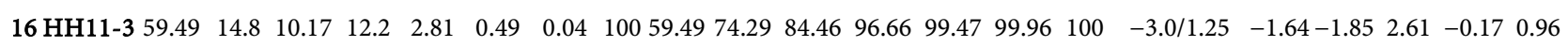

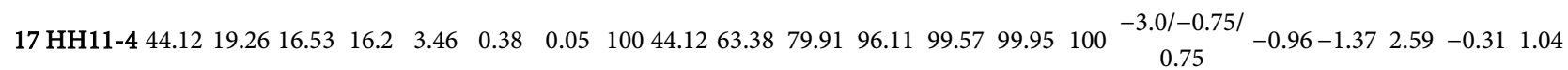

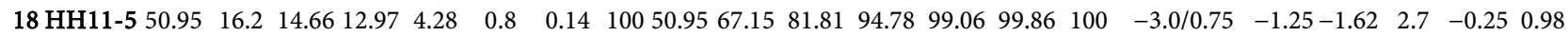

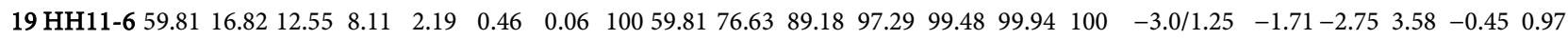

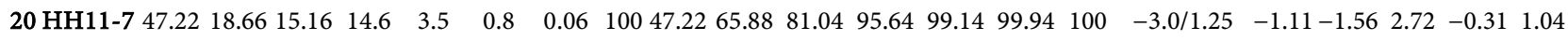

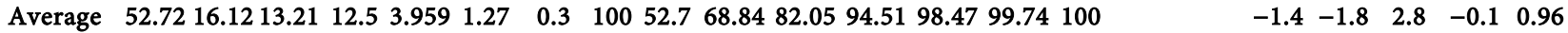

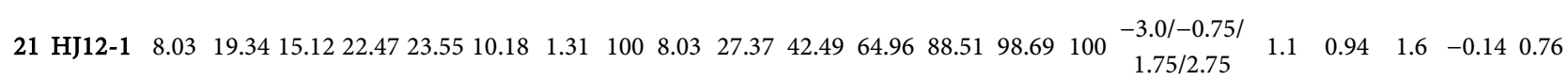

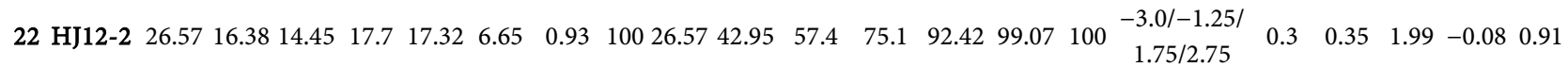

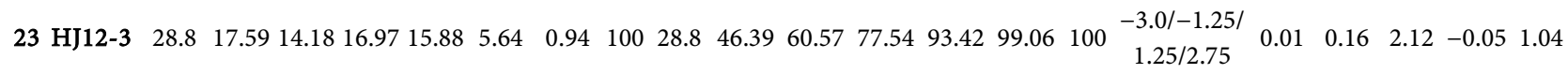

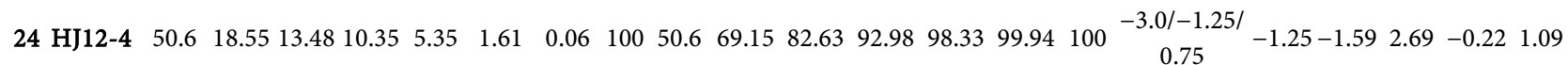

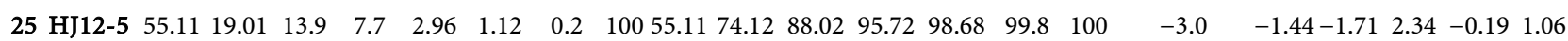

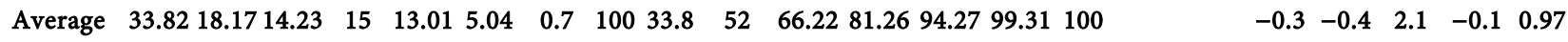

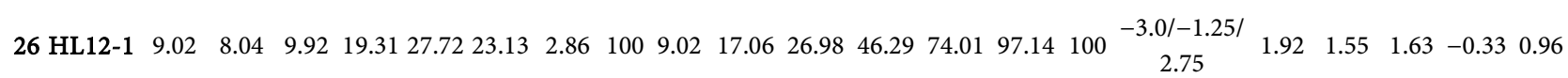

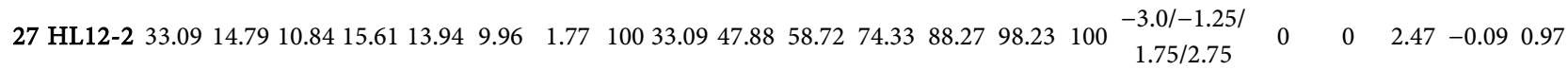

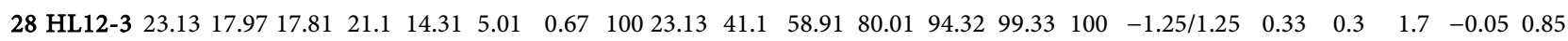

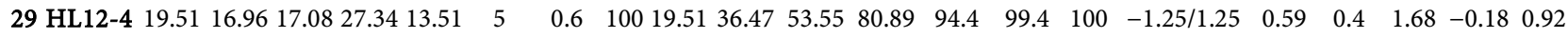

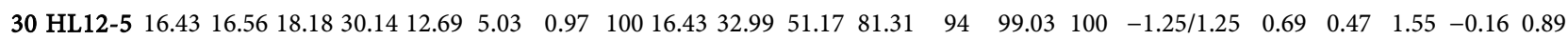

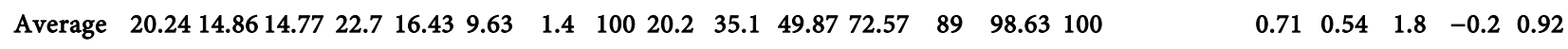

The highest frequency mode was the bi-modal $(10 \times)$, but the tri-modal and the polymodal recorded slightly lesser frequency $(8 \times)$ and come last the uni-modal, which was a frequency only for 3 times. This means that the size distribution is deviated from normal due to the presence of differently size sediments in the same sample. This indicates the presence of unstable and different 
depositional environments of the grains, such as, playa or low depressions, wadi fill deposits and stream channel deposits, and the sediments were deposited in relatively high energetic fluvial medium as gravel, sand and mud sized deposits co-exist, and the sediments are frequently reworked and fed up with new load of sediments.

On average basis, the median recorded negative values $(-1.38-(-0.26) \phi)$ in all the pit holes except the last one to the north of the study area it recorded a positive value $(0.71 \phi)$, the mean grain size changed from coarse sand size $((0.00 \phi: 1.00 \phi)$ to pebbly size $(-2.00 \phi:-6.0 \phi)$, the prevailing sorting class was very poorly sorted class $(2.00 \phi: 4.00 \phi)$, the prevailing skewness class was coarsely skewed $(-0.10 \phi:-0.30 \phi)$ and all the pit holes were of mesokurtic in kurtosis $(0.90 \phi: 1.11 \phi)$. It is worth mentioning that as heading to the north of the study area the mean size has a general trend to change from coarser to finer size. This means that the sediments are of coarse size general trend and the sediments are of fluviatile transportation and frequent reworking and winnowing and reflecting the asymmetrical grains distribution and the multi-sized sediments.

\subsection{Mineralogical Analysis}

\subsubsection{X-Ray Diffraction}

On average basis, the XRD results pit holes' samples showed that Quartz mineral was the predominating constituent in pit holes with a range of $(32.68 \%$ $49.60 \%)$; followed by gypsum mineral with lesser range (16.79\% - 30.38\%). Calcite also recorded lesser amounts than quartz and gypsum (12.56\% - 19.13\%), Microcline $(9.93 \%-10.50 \%)$, then comes dolomite and Montmonilanite with very few percentage $(0.00 \%-0.60 \%)$ and $(0.00 \%-0.31 \%)$, respectively.

\subsubsection{X-Ray Fluorescence (XRF)}

The XRF results obtained for the samples collected from the six vertical pit hole dug in the catchment area of the well-developed drainage network in the study area showed, on average basis, that the predominating oxide is $\mathrm{SiO}_{2}$, i.e., quartz, within the range $(50.69 \%-37.03 \%)$. This range was remarkably quantitatively higher (big difference) than the range of the quantitatively following oxides $\mathrm{CaO}$ (20.81\% - 13.97\%), $\mathrm{SO}_{3}\left(8.26 \%\right.$ - 10.66\%), $\mathrm{Al}_{2} \mathrm{O}_{3}(6.35 \%$ - 3.46\%), $\mathrm{MgO}(2.36 \%-$ 2.04\%), $\mathrm{Na}_{2} \mathrm{O}(2.28 \%-1.81 \%), \mathrm{K}_{2} \mathrm{O}(1.92 \%-1.28 \%)$, and $\mathrm{Fe}_{2} \mathrm{O}_{3}(1.45 \%-1.07 \%)$. The other oxides $\left(\mathrm{MnO}, \mathrm{TiO}_{2}, \mathrm{P}_{2} \mathrm{O}_{5}\right.$, and $\mathrm{SrO}$, are in ranges less than $1 \%$. This supports the suggestion that the existing rocks in the stratigraphy of the area are mostly calcretic gypretic sandy rocks.

\subsubsection{Inductively Coupled Plasma Optical Emission Spectrometer (ICP-OES)}

The data obtained from this analysis showed that, on average basis, calcium (Ca) metal is the predominating in all the holes $(43,198.62-5953.99 \mathrm{mg} / \mathrm{kg})$ followed by iron $(\mathrm{Fe})$, but with considerable difference in recorded values (5079.85 $3298.02 \mathrm{mg} / \mathrm{kg}$ ), and lesser amounts of magnesium $(\mathrm{Mg})(4106.93$ - 1308.79 $\mathrm{mg} / \mathrm{kg}$ ). This suggests that the rocks calcretic or gypcretic with iron-magnesium 
bearing minerals or rock fragments.

\subsubsection{Thin Sections}

According to the analysis of the thin sections prepared from for selected bulk rocky samples extracted from the vertical pit holes, it was shown that these rocks are either calcretic lithic arenite, lithic arenite (greywacke), or wacke mud-supported sandstone. In general, all these rocks are very porous, where the pores are filled with mounting medium with carbonate mud as matrix and silica as cement in the form of quartz over growth. These rocks are formed as the result of rapid uplift and intense erosion and high rate of deposition as a flush. In almost all the samples the matrix clay is affected by varying degrees by carbonate replacement. In some places there is also some kind of diagenetic replacement in carbonates.

\subsection{Surface Hydrology (Basin Analysis)}

\subsubsection{Basin Geology and Geomorphology}

The streams in the well-developed drainage system in the study area are of the ephemeral streams or dry washes that only occasionally have water flowing. They are above the water table and occur in dry climates with low amounts of rainfall and high evaporation rates. They flow mostly during rare flash floods. Using GIS and remote sensing techniques several maps were made for the drainage system in the study area (Figures 9-14), as well as a table showing the characteristics of the basins found in the drainage system of the study area (Table 2).

\subsubsection{Morphometric Analysis and Characteristics Using ArcHydro GIS Technology and STRM Analysis System}

As for the elongation rate, 3 groups were noticed (Table 3): 1) low rate (4 basins),

Table 2. Characteristics of the 10 basins in the drainage system of the study area.

\begin{tabular}{|c|c|c|c|c|c|c|c|c|c|c|c|c|}
\hline \multirow{3}{*}{ Basins } & \multicolumn{12}{|c|}{ Characteristics } \\
\hline & \multicolumn{2}{|c|}{ Order 1} & \multicolumn{2}{|c|}{ Order 2} & \multicolumn{2}{|c|}{ Order 3} & \multicolumn{2}{|c|}{ Order 4} & \multicolumn{2}{|c|}{ Order 5} & \multirow{2}{*}{$\begin{array}{c}\text { Water } \\
\text { divide length } \\
(\mathrm{Km})\end{array}$} & \multirow{2}{*}{$\begin{array}{c}\text { Basin's area } \\
\quad\left(\mathrm{Km}^{2}\right)\end{array}$} \\
\hline & $\begin{array}{c}\text { Length } \\
\text { (m) }\end{array}$ & Number & $\begin{array}{l}\text { Length } \\
\text { (m) }\end{array}$ & Number & $\begin{array}{l}\text { Length } \\
\text { (m) }\end{array}$ & Number & $\begin{array}{l}\text { Length } \\
\text { (m) }\end{array}$ & Number & $\begin{array}{l}\text { Length } \\
\text { (m) }\end{array}$ & Number & & \\
\hline Basin 1 & 25,911 & 54 & 15,788 & 25 & 7387 & 16 & 4320 & 1 & 0 & 0 & 32 & 28 \\
\hline Basin 2 & 45,388 & 133 & 20,279 & 22 & 31,050 & 7 & 4321 & 2 & 4951 & 1 & 66 & 88 \\
\hline Basin 3 & 61,572 & 123 & 23,459 & 37 & 29,891 & 8 & 1207 & 3 & 8342 & 1 & 59.7 & 85.7 \\
\hline Basin 4 & 9346 & 23 & 8830 & 3 & 3728 & 1 & 0 & 0 & 0 & 0 & 23 & 15 \\
\hline Basin 5 & 10,543 & 24 & 2061 & 3 & 6811 & 1 & 5746 & 1 & 0 & 0 & 33 & 13.5 \\
\hline Basin 6 & 36,556 & 83 & 11,617 & 3 & 3300 & 2 & 15,470 & 1 & 2959 & 1 & 57 & 50 \\
\hline Basin 7 & 7544 & 21 & 5603 & 3 & 2088 & 1 & 6196 & 1 & 0 & 0 & 33 & 13 \\
\hline Basin 8 & 12,208 & 12 & 20,501 & 25 & 14,462 & 5 & 19,168 & 1 & 0 & 0 & N/A & 81 \\
\hline Basin 9 & 12,425 & 39 & 4966 & 9 & 10,096 & 1 & 0 & 0 & 0 & 0 & 30 & 17 \\
\hline Basin 10 & 24,491 & 43 & 23,792 & 7 & 1789 & 1 & 0 & 0 & 0 & 0 & 31 & 33 \\
\hline
\end{tabular}




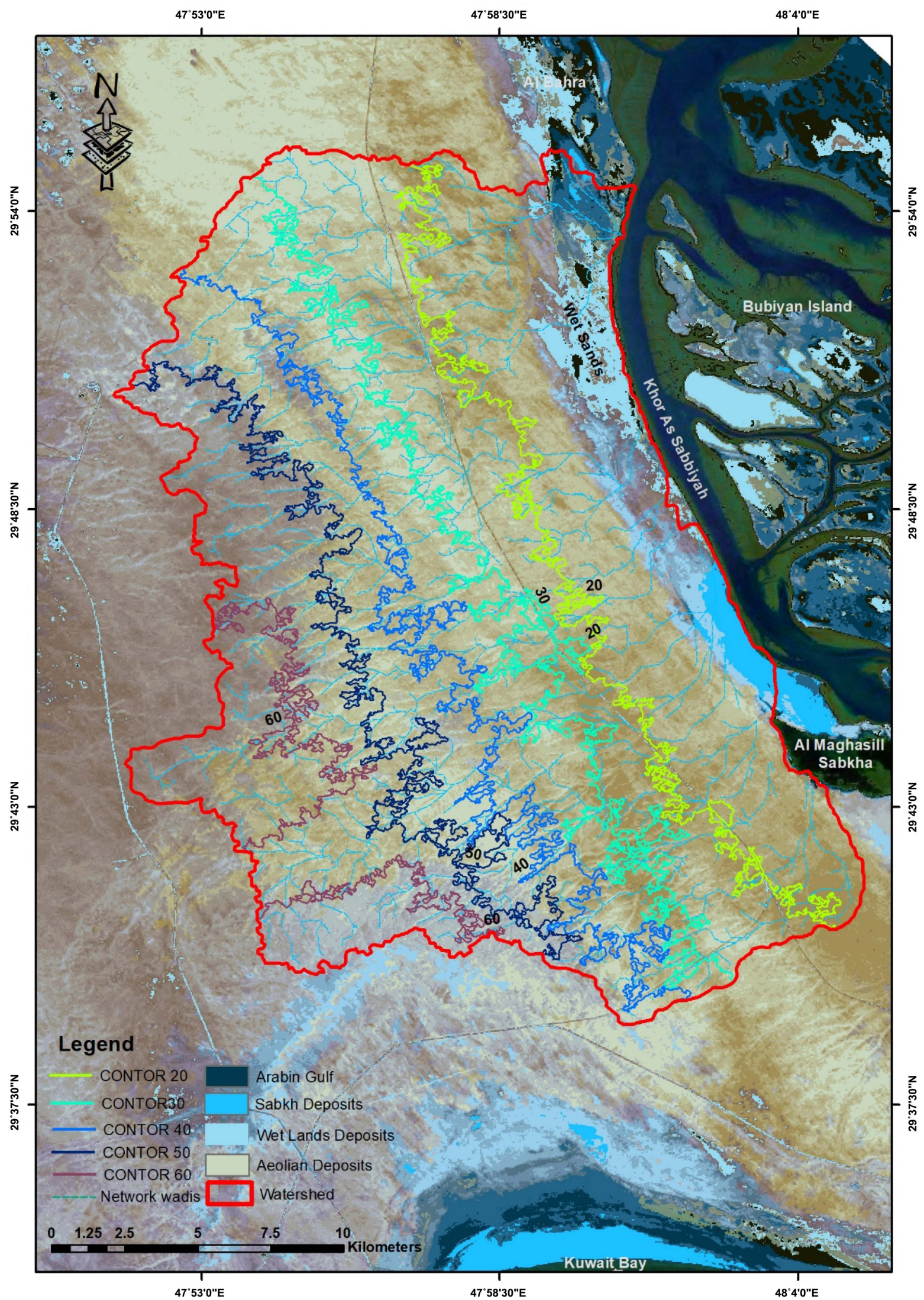

Figure 9. Contour map of the catchment area in As Sabriyah area. 


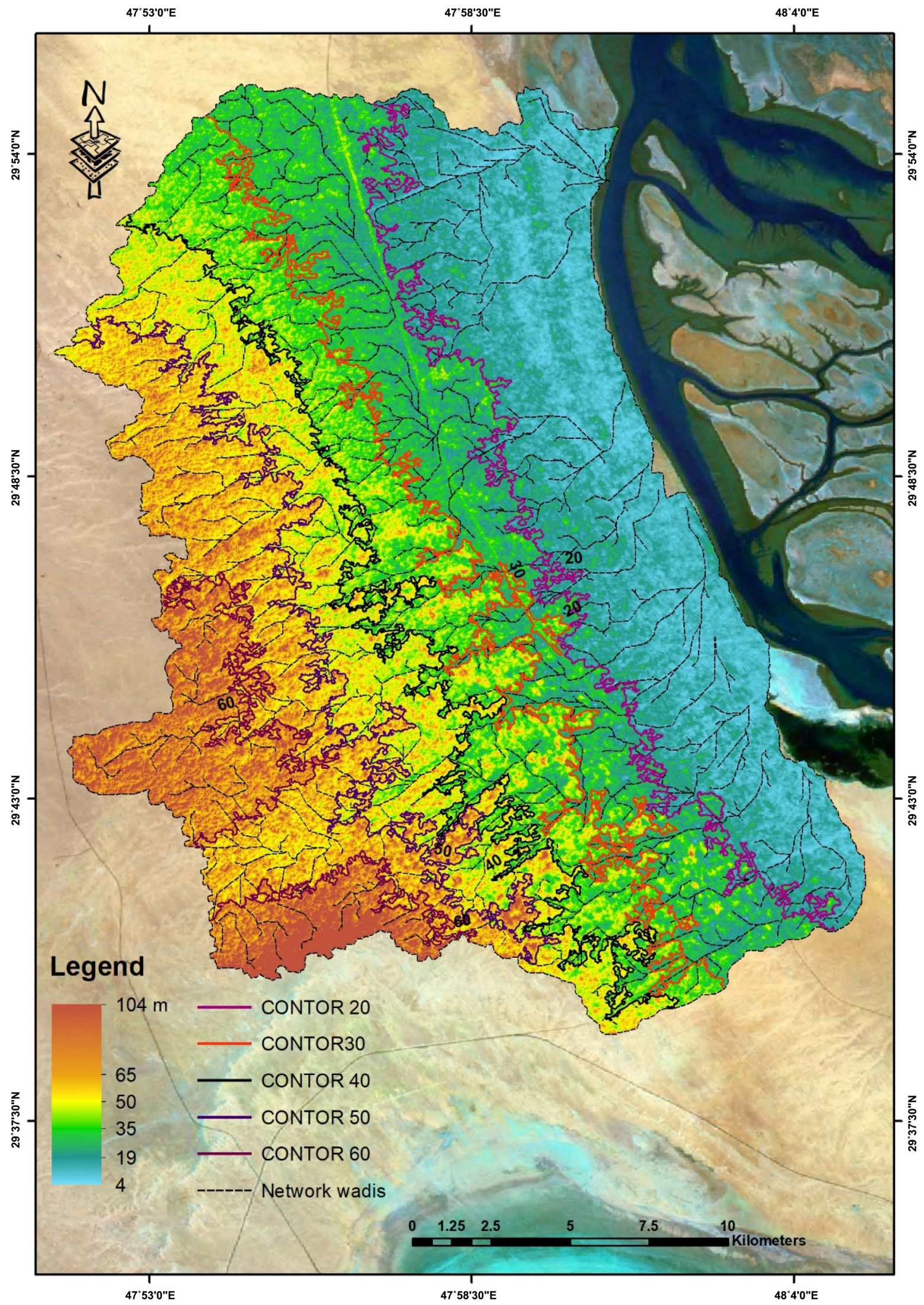

Figure 10. Contour map of the study area with the network wadis. 


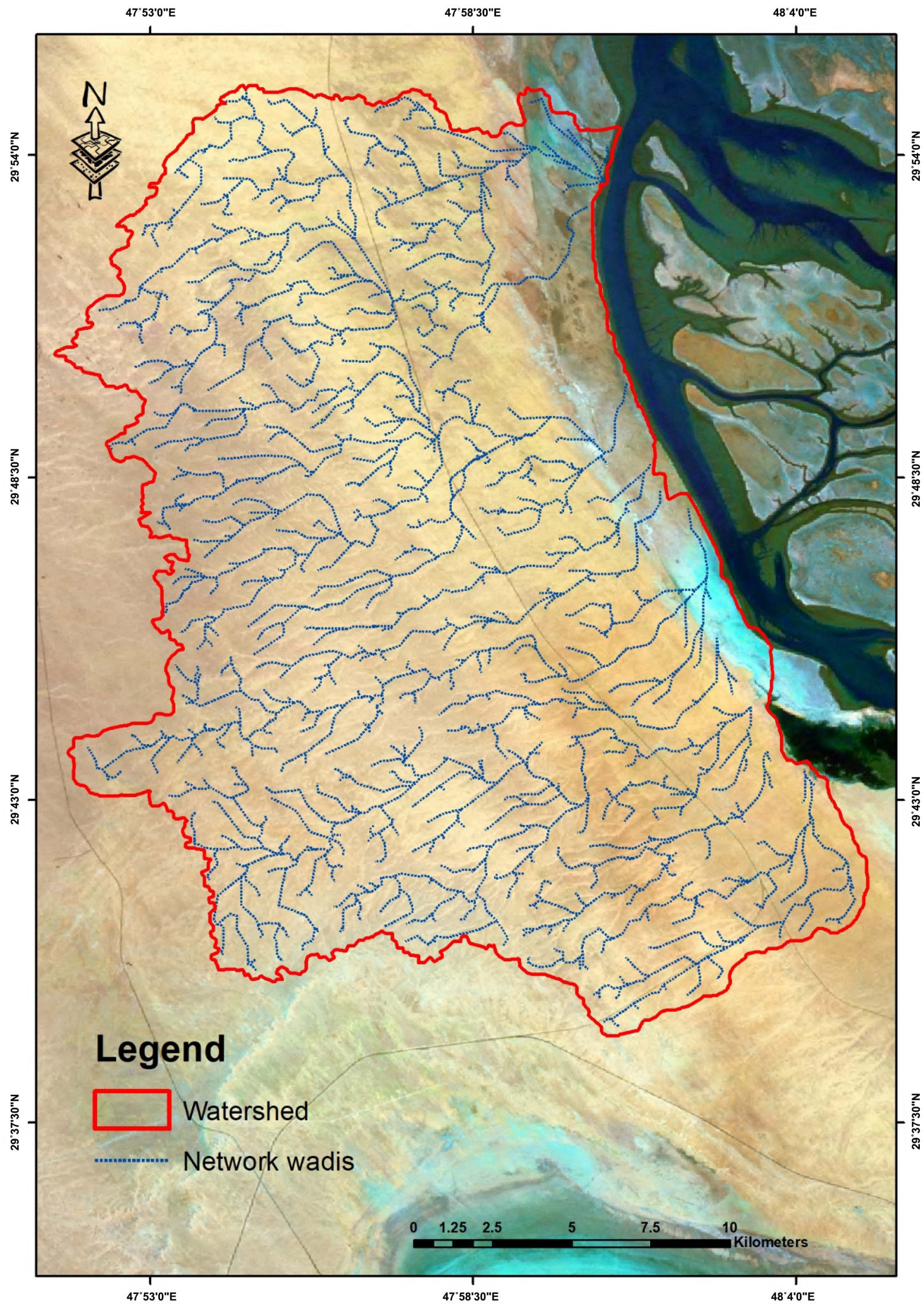

Figure 11. The pattern of the network wadis in the study area. 


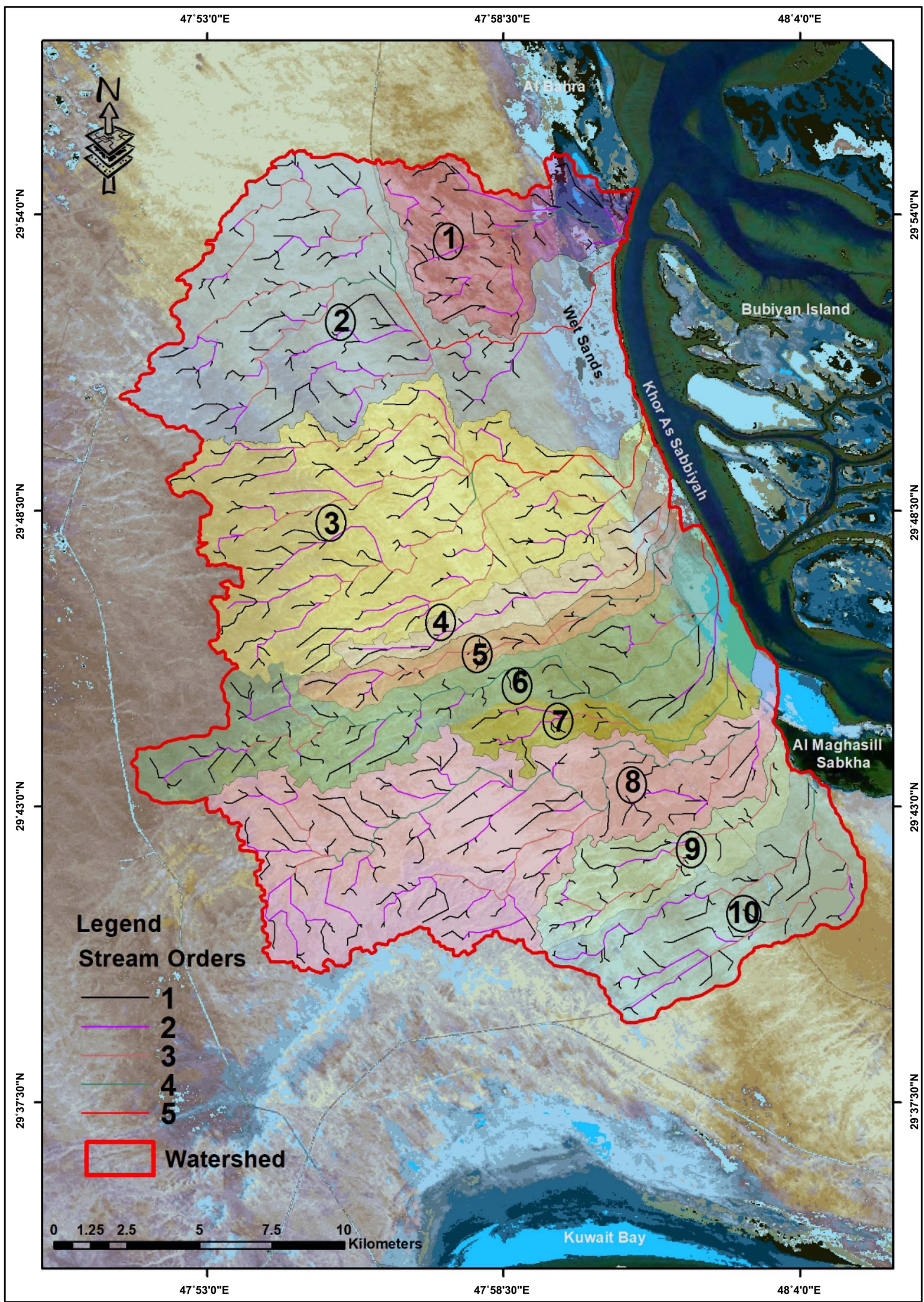

Figure 12. The basins of network wadis in the study area with their orders. 


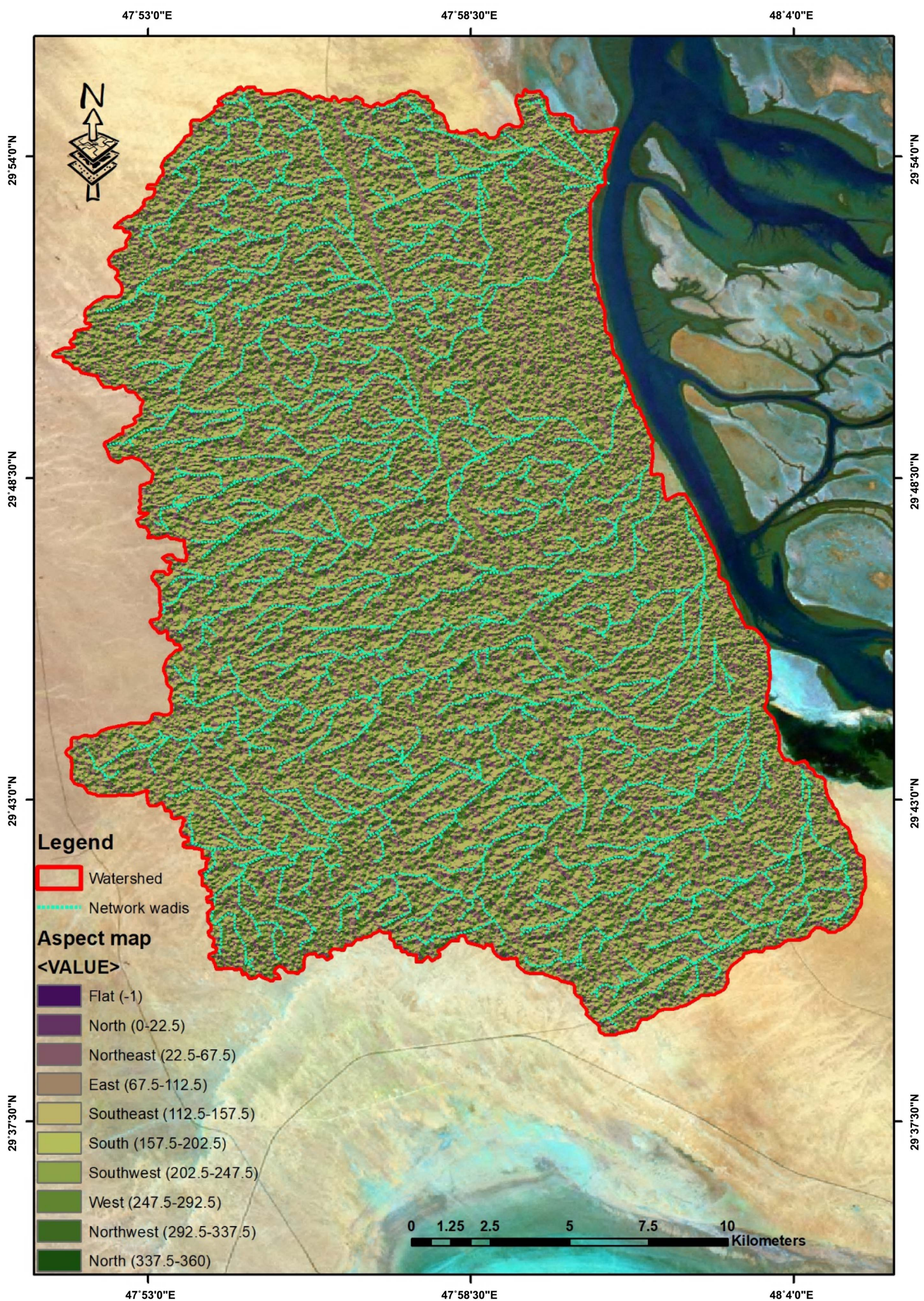

Figure 13. An aspect map of the drainage basin indicating the slope directions in the network wadis of the drainage system in the study area. 


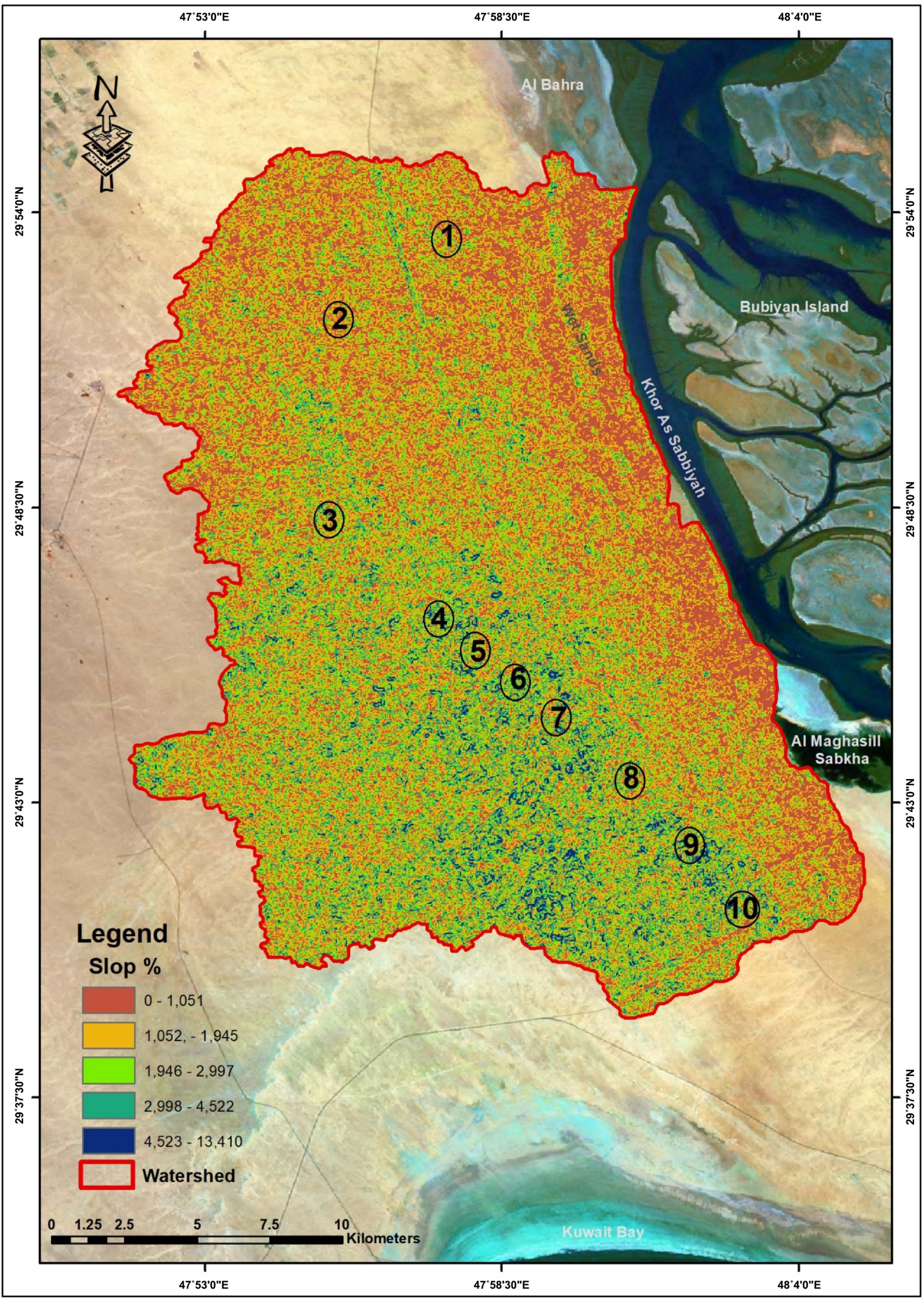

Figure 14. A map indicating the slope gradient ranges in basins of the drainage system of the study area. 
Table 3. Morphometric parameters of the network wadis in the drainage basin in As Sabriyah area.

\begin{tabular}{|c|c|c|c|c|c|c|c|c|}
\hline Basin & $\begin{array}{c}\text { Area } \\
\left(\mathrm{km}^{2}\right)\end{array}$ & $\begin{array}{c}\text { Perimeter } \\
\qquad(P) \\
(\mathrm{m})\end{array}$ & $\begin{array}{l}\text { Length } \\
\quad(L) \\
(\mathrm{m})\end{array}$ & $\begin{array}{l}\text { Width } \\
(W) \\
(\mathrm{m})\end{array}$ & $\begin{array}{c}\text { Form } \\
\text { factor } \\
\left(F_{f}\right)\end{array}$ & $\begin{array}{c}\text { Circularity } \\
\text { ratio } \\
\left(R_{c}\right)\end{array}$ & $\begin{array}{c}\text { Elongation } \\
\text { ratio } \\
\left(R_{e}\right)\end{array}$ & $\begin{array}{c}\text { Combination } \\
\text { coefficient } \\
\left(C_{c}\right)\end{array}$ \\
\hline 1 & 28 & 66 & 7 & 4 & 0.5714 & 0.0808 & 0.8532 & 3.5435 \\
\hline 2 & 88 & 66 & 14 & 7 & 0.449 & 0.2539 & 0.7363 & 1.9988 \\
\hline 3 & 85.7 & 60 & 13 & 7 & 0.5059 & 0.2985 & 0.8028 & 1.8435 \\
\hline 4 & 15 & 23 & 14 & 1.5 & 0.0765 & 0.3564 & 0.3122 & 1.6871 \\
\hline 5 & 13.5 & 33 & 12 & 1.8 & 0.833 & 0.1385 & 0.3258 & 2.7064 \\
\hline 6 & 50 & 57 & 13 & 1.2 & 0.2959 & 0.1934 & 0.6139 & 2.2901 \\
\hline 7 & 13 & 33 & 13 & 1.8 & 0.0799 & 0.1558 & 0.319 & 2.5516 \\
\hline 8 & 81 & 71 & 18 & 4.5 & 0.25 & 0.202 & 0.5643 & 2.2412 \\
\hline 9 & 17 & 30 & 9.5 & 1.8 & 0.1884 & 0.2374 & 0.4899 & 2.0671 \\
\hline 10 & 33 & 31 & 9.7 & 3 & 0.3507 & 0.4316 & 0.6684 & 1.5331 \\
\hline
\end{tabular}

2) high rate (3 basins of high elongation rate), 3) 3 basins relatively rectangular and dented in their middle sector with shorter lengths than of the other 2 groups. Most of the basins are of very low circularity rate (0.13 - 0.43), not support the symmetry in the concentration of on basins' slopes and slowing the flow in the streams during precipitation. Most of the form factors values are among the values of elongated basins. Middle sector of basins (4 - 8) and southern and western sectors of basins ( $9 \& 10$ ) are of high slope gradient, whereas their lower sectors are of low slope gradients as getting closer to Khor Al-Sabbiyah, which might be due to the Arabian Gulf sea paleo-transgression movement and erosional levelling of the stream sectors. Basins $(1 \& 2)$ are of relatively high slope gradients compared to the previous basins. All of the basins are of high combination coefficient, which strongly supporting the elongation of most of the drainage basins and away from the circular form.

\subsection{Interpretation of Stratigraphic Settings}

Figure 15 shows the Correlation of the 6 stratigraphic columns constructed from the analysis of the samples taken from the 6 vertical pits from the study areas showing the 5 main dominant components: gravels (mainly quartz), sands, mud, calcite, and gypsum found in the 6 interpreted facies. The lateral and vertical distribution of these sediments is highly controlled by four major factors: general slope, local relief, drainage pattern and frequent storms. According to the lithofacies and stratigraphic correlation, it was found that the area is dominated by coarse-grained sediments with considerable fractions of gypsum, silts, and calcite. These types of loose sediment are characterized by high porosity and permeability, so the rate of infiltration is relatively high. Therefore, during frequent rain storms significant amounts of water may infiltrate through the sediments. This infiltrated water would have lower or limited chance to percolate due to the rigid underlying bed rocks and hence eventually directed to the sea 
driven by the general slope and dip of strata trending seaward. As a result, there is a very limited chance of recharging from the well-developed drainage network in the area to the shallow aquifers.

Kuwait Group possesses a groundwater level that varies from about 80 to $90 \mathrm{~m}$ above sea level in the southwest to near ground level along the coast $(2-20 \mathrm{~m}$ in the study area) [3]. The calculated total gradient in the study area is about $0.214 \%$ seaward. The Ghyben-Herzberg relation (which states, for every $1 \mathrm{~m}$ of fresh water in an unconfined aquifer above sea level (as the case in the study area) (Figure 16), there will be $40 \mathrm{~m}$ meters of fresh water in the aquifer below

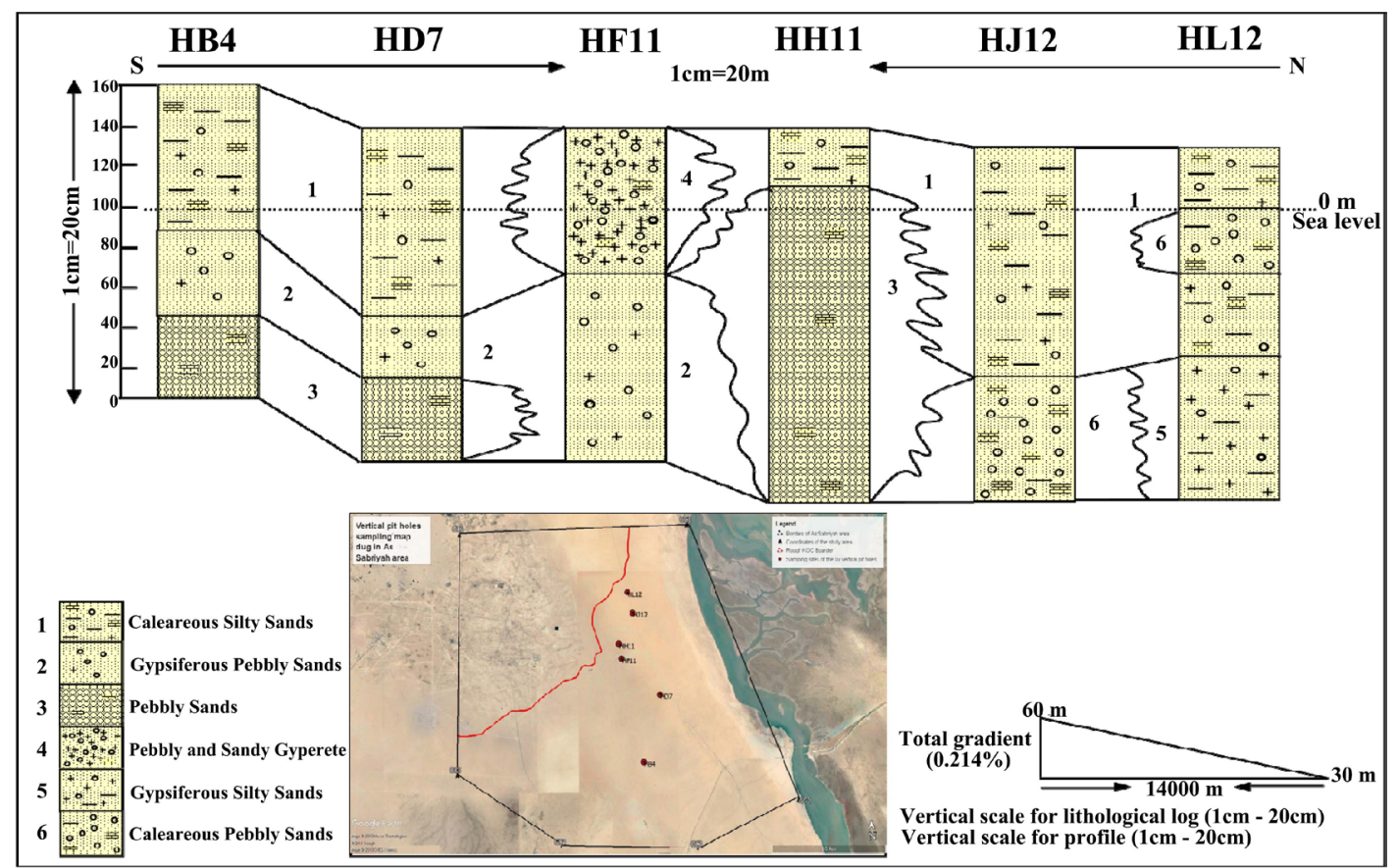

Figure 15. Correlation of the 6 stratigraphic columns constructed from the analysis of the samples taken from the 6 vertical pits from the study areas showing the 5 main dominant components: gravels (mainly quartz), sands, mud, calcite, and gypsum found in the 6 interpreted facies.

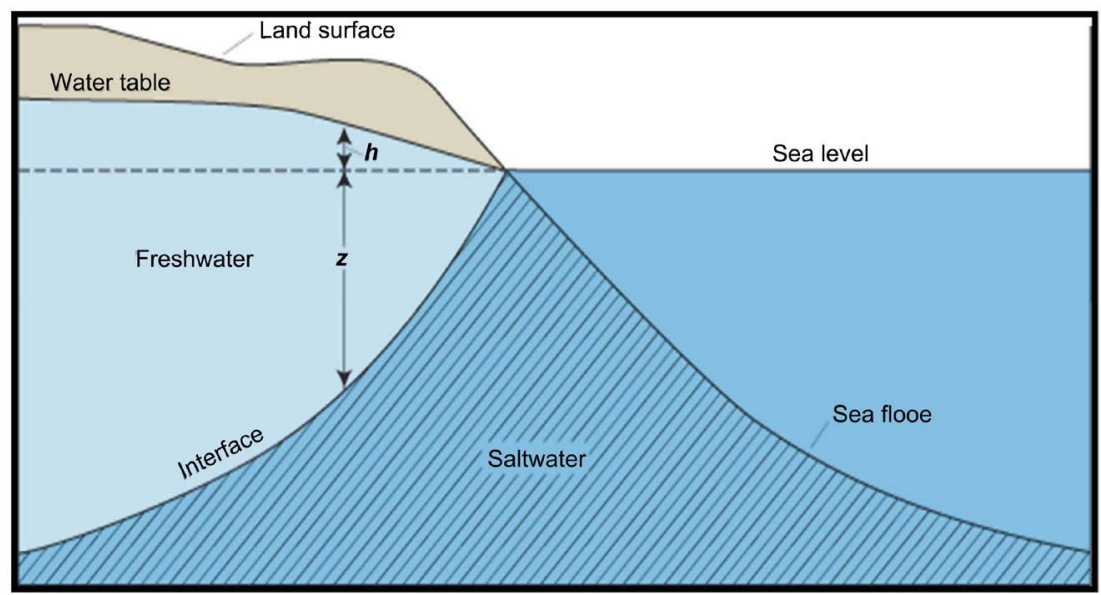

Figure 16. The Ghyben-Herzberg relation. Where the thickness of the freshwater zone above sea level is represented as $h$ and that below sea level is represented as $Z$ (after [28]). 


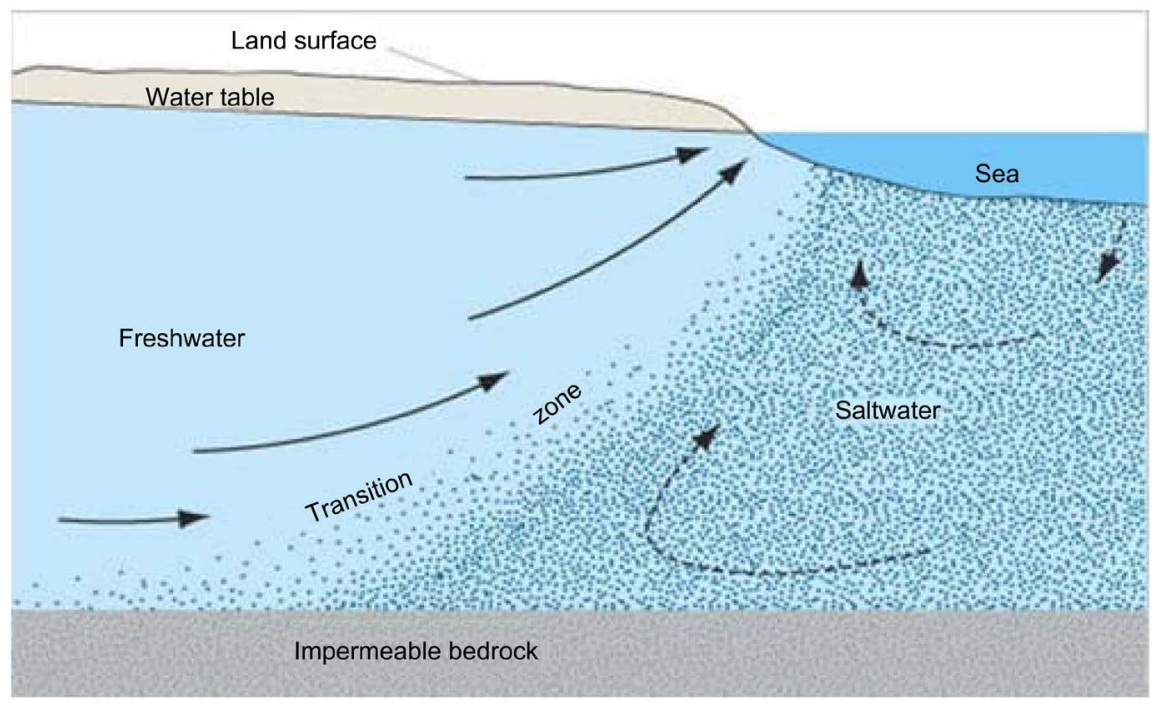

Figure 17. Groundwater flow patterns and the freshwater-saltwater transition zone. A circulation of saltwater from the sea to the transition zone and then back to the sea is induced by mixing of freshwater and saltwater in the transition zone (after [28]).

sea level). Accordingly, the movement of surface runoff and infiltrated water towards the sea is suggested to contribute in the stabilization of fresh water-saline water interface, and hence oppose the salt water intrusion, which consequently might play a significant role in enhance the water quality in the shallow aquifers (Figure 17).

\section{Conclusions}

The well-developed paleo-drainage system in As Sabriyah area is composed of 10 closely spaced drainage basins, which are subparallel dendritic elongated variant-sloped and of high compactness coefficient, of an area of $\left(13-88 \mathrm{~km}^{2}\right)$, a length of $(7-18 \mathrm{Km})$, a width of $(1.2-7 \mathrm{Km})$, with highest stream order of 5 , where water flows $\mathrm{NE}$ from Al-Rukham ridge's crest (60 $\mathrm{m}$ a.m.s.l.) downstream in Khor Al-Subiyah coastal flat.

The hard resistant calcretic and gypretic gravelly sand deposits in the upper Dibdibba Formation lowered its infiltration and recharging capacity to the shallow aquifer, but retained the well-developed drainage network. Whereas the coarse-grained sediments with considerable fractions of gypsum, silts, and calcite of the friable gravelly sand or aeolian sand nature of the wadi fill deposits increased the infiltration capacity of the surface sediment. Thus, infiltrated water would have limited chance to percolate and eventually directed to the sea by the general topography of the area seaward, which would be of limiting potential recharge from the well-developed drainage network to the shallow aquifers.

According to Ghyben-Herzberg ratio for the fresh-salt water interface, the movement of surface runoff and infiltrated water towards the sea in the study area is suggested to contribute in the stabilization of fresh water-saline water interface, and hence oppose the salt water intrusion, which consequently might 
play a significant role in enhancing the water quality in the shallow aquifers.

\section{Recommendations}

Any development management plan to be implemented in the study area should take into consideration the pattern and distribution of the well-developed paleodrainage network in the area for the following important issues:

1) Since surface runoff is of high potential to infiltrate through the surface wadi fills sediments of the drainage system in the area rather than the surrounding and underlying rigid calcretic gypcretic bedrock, the outcomes of this study should be considered for the morphometric characteristics of the existing drainage system as it is highly potential to play a significant role in water harvesting feasibility in the desert of Kuwait.

2) Knowing that such areas might be very susceptible to salt water intrusion due to pumping from the lower shallow aquifers, as if pumping lowers the water table by $1 \mathrm{~m}$, the thickness of the freshwater body within the aquifer will decrease by approximately $40 \mathrm{~m}$, according to Ghyben-Herzberg relation, thus allowing the denser saltwater at depth to "intrude" into the aquifer. Therefore, careful management of groundwater pumping in such areas is required to avoid the intrusion of saltwater into the freshwater aquifer.

3) The significant role of the well-developed drainage network in As Sabriyah area and its beneficiary contribution to hydrogeological matter of concern should be taken into consideration in any future developmental plans in the area.

\section{Acknowledgements}

Authors are grateful to the research administration in Kuwait University for financing this project SE02/14. Thanks are also extended to the Earth and Environmental Sciences Department, Faculty of Science, Kuwait University, for providing laboratories facilities, as well as, to Research Sector Projects Unit (Project no. GS 01/01), NUERS (Project No: SRUL01/13). Thanks are also extended to Mrs. Nehaya Saied, Mr. Nabil Basilli, and Mr. Yousif Abdullah from Earth and Environmental Sciences Department for their devoted assistance in the field and laboratory work, as well as statistical analysis.

\section{Conflicts of Interest}

The authors declare no conflicts of interest regarding the publication of this paper.

\section{References}

[1] Al-Hurban, A. (2014) Effects of Recent Anthropogenic Activities on the Surface Deposits of Kuwait. Arabian Journal of Geosciences, 7, 665-691. https://doi.org/10.1007/s12517-013-0866-9

[2] Ministry of Defense (1995) Kuwait Topographic Map (Scale 1:250,000). 3rd Edition, 
Survey Department. The General Staff Headquarters. Ministry of Defence, Kuwait.

[3] Al-Sulaimi, J., Khalaf, F.J. and Mukhopadhyay, A. (1997) Geomorphological Analysis of Paleo Drainage Systems and Their Environmental Implications in the Desert of Kuwait. Environmental Geology, 29, 94-111. https://doi.org/10.1007/s002540050108

[4] Al-Sulaimi, J. and El-Rabaa, S.M. (1994) Morphological and Morphostructural Features of Kuwait. Geomorphology, 11, 151-167. https://doi.org/10.1016/0169-555X(94)90079-5

[5] Kleo, A. (1988) Wadis of Jal Az-zor Kuwait. A Geomorphological Analysis. Kuwait University, Kuwait, 76 p.

[6] Al-Hurban, A. and Hersi, A. (2008) Sedimentomorphic Mapping of Jal Az-Zor Escarpment, Northern Kuwait, Using GIS Methods. Kuwait Journal of Science and Engineering, 35, 93-128.

[7] Al-Ruwaih, F. (1993) Groundwater Exploration in North Kuwait. Journal of University of Kuwait (Science), 20, 293-310.

[8] Al-Ruwaih, F. and Shehata, M. (2007) Consistency of Dry Basin Hydraulic Geometry and Its Relationship with Basin Morphology and Hydrology of Kuwait. Water International.

[9] El-Baz, F. and Al-Sarawi, M. (2000) Atlas of the State of Kuwwait from Satellite Images. Kuwait Foundation for the Advancement of Sciences (KFAS), Kuwait.

[10] KISR (1995) Geomorphic Zones of Kuwait. Kuwait Institute for Scientific Research, Kuwait, Map (Unpublished).

[11] Parsons Corporation (1963) Groundwater Resources of Kuwait. Ministry of Electricity and Water, Kuwait (Unpublished).

[12] Himida, I. and El-Yaqubi, S. (1979) Hydrogeological and Hydrogeochemical Aspects of the Main Groundwater Fields in Kuwait, Arabian Gulf. First Geological Congress of the Middle East (GEOCOME-1), Ankara, 4 p.

[13] Burdon, D. and Al-Sharhan, A. (1968) The Problem of the Palaeokarstic Dammam Limestone Aquifer in Kuwait. Journal of Hydrology, 6, 358-404.

https://doi.org/10.1016/0022-1694(68)90057-7

[14] Al-Ruwaih, F. and Hadi, K. (2005) Water Quality Trends and Management of Fresh Groundwater at Al-Rawdhatain, Kuwait. European Journal of Scientific Research, 9, 40-64.

[15] Mukhopadhyay, A., Al-Sulaimi, J., Al-Awadhi, E. and Al-Ruwaih, F. (1996) An Overview of the Tertiary Geology and Hydrogeology of the Northern Part of the Arabian Gulf Region with Special Reference to Kuwait. Earth Science Reviews, 40, 259-295. https://doi.org/10.1016/0012-8252(95)00068-2

[16] Al-Sulaimi, J. and Al-Ruwaih, F. (2004) Geological, Structural, and Geochemical Aspects of the Main Aquifer Systems in Kuwait. Journal of Science and Engineering, 31, 149-174.

[17] Al-Smait and Al-Rashid (1997) Hydrological Situation of Kuwait. The 7 th Conference of the Permanent Arabic Committee for Hydrological Programs, Rabat, 8-12 September 1997, $30 \mathrm{p}$.

[18] Al-Sayari, S.S. and Zotl, J.G. (1978) Quaternary Period in Saudi Arabia. Springer-Verlag, Wien, 335. https://doi.org/10.1007/978-3-7091-8494-3

[19] Al-Sulaimi, J. and Al-Ruwaih, F. (2005) Geology and Natural Resources of Kuwait. Authorship Translation and Publication Committee, Kuwait.

[20] Al-Sulaimi, J. and Mukhopadhyay, A. (2000) An Overview of the Surface and Near- 
Surface Geology, Geomorphology and Natural Resources of Kuwait. Earth Science Reviews, 50, 227-267. https://doi.org/10.1016/S0012-8252(00)00005-2

[21] Horton, R. (1932) Drainage Basin Characteristics. Transactions of the American Geophysical Union, 13, 360-361. https://doi.org/10.1029/TR013i001p00350

[22] Strahler, A.N. (1952) Hypsometric (Area-Altitude) Analysis of Erosional Topography. Bulletin of Geological Society of America, 63, 1117-1142. https://doi.org/10.1130/0016-7606(1952)63[1117:HAAOET]2.0.CO;2

[23] Schumm, S.A. (1956) The Evolution of Drainage Systems and Slopes in Badlands at Perth Amboy, New Jersey. Geological Society of America Bulletin, 67, 597-646. https://doi.org/10.1130/0016-7606(1956)67[597:EODSAS]2.0.CO;2

[24] Melton, M. (1957) An Analysis of the Relations among Elements of Climate, Surface Properties and Geomorphology. Department of Geology, Columbia University, Technical Report, 11, Project NR 389-042. Office of Navy Research, New York. https://doi.org/10.21236/AD0148373

[25] Miller, V.C.A. (1953) Quantitative Geomorphic Study of Drainage Basin Characteristics in the Clinch Mountain Area. Virginia and Tennessee, Project Number 389-402. Technical Report-3, Columbia University, Department of Geology, New York.

[26] Folk, R. (1954) The Distinction between Grain Size and Mineral Composition in Sedimentary Rocks. Journal of Geology, 62, 344-359.

https://doi.org/10.1086/626171

[27] Folk, R. and Ward, W. (1957) Brazos River Bar, a Study in the Significance of Grain Size Parameters. Journal of Sedimentary Petrology, 27, 3-27. https://doi.org/10.1306/74D70646-2B21-11D7-8648000102C1865D

[28] Barlow, P.M. (2003) Occurrence and Flow of Freshwater and Saltwater in Coastal Aquifers. In: Barlow, P.M., Ed., Ground Water in Freshwater-Saltwater Environments of the Atlantic Coast, U.S. Geological Survey, Reston, Chapter 1. https://doi.org/10.3133/cir1262 